\title{
Paquita Baylina: uma trajetória musical esquecida no sul do Brasil
}

\author{
Humberto Amorim* \\ Universidade Federal do Rio de Janeiro \\ humberto-amorim@hotmail.com \\ Daniel Wolff** \\ Universidade Federal do Rio Grande do Sul \\ daniel@danielwolff.com
}

* Professor da Universidade Federal do Rio de Janeiro desde 2007. Doutor em Musicologia e Mestre em Práticas Interpretativas.

** Professor Titular da Universidade Federal do Rio Grande do Sul. Bacharel em Música pela Escuela Universitária de Música (Universidad de la República, Montevidéu); Mestre e Doutor em Música pela Manhattan School of Music (Nova lorque).

Submetido em 23/04/2018, Aprovado em 19/07/2018 


\section{Resumo}

Com ênfase em sua atuação artística, o artigo resgata traços biográficos de $\mathrm{Pa}$ quita Baylina, musicista gaúcha que teve significativa participação na cena cultural de Porto Alegre entre os anos de 1910 e 1923. Personagem desconhecida nos estudos sobre o tema, Paquita teve aulas com o cego Levino Albano da Conceição e chegou a vencer um concurso instrumental em 1914, angariando prestígio e reconhecimento em um ambiente predominantemente masculino. Contudo, suas atividades musicais foram bruscamente interrompidas pelo casamento, em 1923, fator determinante para que sua dupla atuação permanecesse obliterada por décadas: inicialmente, como a primeira violonista de que se tem notícia a apresentar um repertório solista nos principais palcos musicais da cidade (incluindo apresentações no Theatro São Pedro); depois, como figura desbravadora na prática simultânea do canto acompanhado por violão. Com a reunião de quase 100 fontes inéditas recolhidas em revistas e jornais publicados no Rio Grande do Sul, Rio de Janeiro e Bahia, foi possível remontar alguns aspectos de sua trajetória musical, retirando da penumbra uma mulher considerada pela crítica de seu tempo como "exímia", "inteligente" e "distinta virtuose".

Palavras-chave: Paquita Baylina; Música no Rio Grande do Sul; Violão em Porto Alegre; Mulheres violonistas brasileiras; Levino Albano da Conceição.

\section{Abstract}

With an emphasis on her artistic work, the present article recovers biographical traces of Paquita Baylina, a musician from Rio Grande do Sul who had a significant role in Porto Alegre's cultural scene between the years 1910-1923. An unknown figure in the present day, Paquita had lessons with the blind teacher Levino Albano da Conceição and won a performance competition in 1914, thus acquiring prestige and recognition in a predominantly male environment. However, her musical activities were suddenly interrupted by her wedding in 1923, a factor which caused her double role to remain obscured for decades: as the probable first female guitarist to perform solo repertoire in the city's main musical venues (including performances at the São Pedro theatre), and as a forerunner of the simultaneous practice of singing with guitar accompaniment. Upon gathering almost 100 previously unknown sources in magazines and newspapers, mostly from Rio Grande do Sul, but also from Rio de Janeiro and Bahia, it was possible to reconstruct the most important aspects of her musical career, bringing to light a woman that was considered by the critics of her time as a "skilled", "intelligent" and "distinct virtuosa".

Keywords: knowledge production; ethnic-racial diversity; school practices. 
De maneira geral, ainda são poucos os trabalhos que apontam para o papel desempenhado pelas mulheres nas trajetórias do violão no Brasil, dentre os quais despontam os desenvolvidos por Porto e Nogueira (2007), Taborda (2013), Ruas Junior (2014) e, mais recentemente, Lacerda (2017) e Amaral (2017), esta última promissora violonista e pesquisadora brutalmente assassinada em um crime de feminicídio realizado pouco depois da finalização de sua pesquisa de mestrado, sobre cinco compositoras brasileiras que dedicaram obras para o instrumento.

Contudo, a par das decisivas contribuições, estas pesquisas apresentam um traço em comum: abordam a trajetória de mulheres nascidas ou atuantes no eixo Rio de Janeiro-São Paulo. Se, nestes dois estados, o panorama ainda é parco e segue em construção através do arguto engajamento das (os) pesquisadoras (es) mencionadas (os), pode-se imaginar o quão este quadro é ainda mais incipiente nas outras regiões do país, nas quais muitas vezes as mulheres tiveram suas histórias e contribuições musicais completamente obliteradas.

É o caso da gaúcha Paquita Baylina, que, entre os anos de 1910 e 1923, abriu caminhos para o violão nos principais palcos de Porto Alegre, coordenando eventos, realizando dezenas de apresentações e chegando a vencer um concurso instrumental como violonista.

No século XIX, as práticas musicais realizadas por mulheres estavam bastante divididas, entre aquelas socialmente aceitáveis e ligadas ao espaço doméstico, e aquelas não tão aceitáveis e ligadas ao espaço cênico-profissional. As oportunidades que possuíam as mulheres de realizar uma aproximação aos círculos de música ou às academias de arte estavam bastante dificultadas pelo fato de que as atividades artísticas eram, neste momento, consideradas adequadas somente aos homens. (PORTO; NOGUEIRA, 2007, p. 2)

A atividade musical desempenhada por Paquita furou duplamente esta bolha: tanto ao inserir-se nos círculos da música, chegando a realizar apresentações no Theatro São Pedro; quanto por gozar de uma formação acadêmica dentro de prestigiados centros musicais. Contudo, depois de alcançar prestígio em um ambiente predominantemente ocupado por homens, Paquita teve sua trajetória artística duplamente silenciada: em vida, quando o casamento encerrou definitivamente suas atividades musicais públicas; e, depois de sua morte, com a ausência de pesquisas (sobretudo na região) que nos permitissem dimensionar a participação das mulheres na construção dos espaços - práticos e simbólicos - ocupados pelo violão na dinâmica sociocultural brasileira.

Diante do fato, o propósito do artigo é resgatar traços de sua trajetória e atuação artística, visando demonstrar não somente o quão sua presença pode ter sido significativa na cena cultural do Rio Grande do Sul em princípios do século XX, mas também de que modo Paquita se articulou em (e através de) uma estrutura social que projetava sobre as mulheres uma visão ideal, moldada por um padrão de comportamento bem determinado.

Como se trata de personagem desconhecida nos estudos sobre o tema, cumpre realizar, inicialmente, um esboço biográfico que nos permita vislumbrar de que maneira 
seu percurso de vida se entrecruza com seus feitos musicais, descortinando os espaços e contextos dos quais sua figura emerge.

\section{Traços biográficos}

Embora sejam raras as notícias sobre os primeiros anos de vida de Paquita Angelina Baylina (? -1962), sabe-se que seu nascimento ocorreu no dia 18 de abril e muito provavelmente na última década do século XIX. Natural do Rio Grande do Sul, a professora e musicista (violonista, pianista, bandolinista e cantora) teve como mãe a Sra. Mercedes Garrido de Baylina, mulher que enviuvou com as duas filhas ainda jovens (A FEDERAÇÃO, 1917a). Sobre seu pai, não encontramos quaisquer informações nos periódicos investigados.

Dentre seus familiares mais próximos, averiguamos que Paquita teve uma irmã também musicista: a bandolinista Maria Baylina, que, em Porto Alegre, participou de diversos eventos artísticos e sociais (muitos dos quais ao lado de Paquita) sobretudo entre 1910 e 1916, ano em que contrai matrimônio com o Sr. Luiz Saint Clair de Abreu e, musicalmente, deixa de atuar em público. O enlace foi anunciado no ano anterior, em 28 de dezembro de 1915, quando o jornal gaúcho A Federação publica o "Contracto de Casamento" entre ambos.

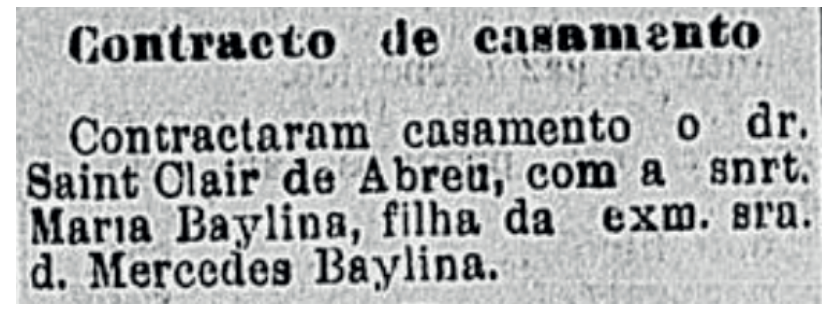

Fig. 1. Contrato de casamento entre Maria Baylina e Saint Clair. Fonte: (A FEDERAÇÃO, 1915a).

Maria Baylina seguiu atuando como professora de música nos anos seguintes, mas o casamento, na prática, encerrou suas participações como instrumentista na cena musical rio-grandense. Em algum momento entre as décadas de 1920 e 1930, ela e o marido acabaram se estabelecendo no Rio de Janeiro, onde este faleceu em junho de 1936 (A NOITE, 1936). Em terras cariocas, a irmã de Paquita liderou por décadas a congregação Pia União de Santa Rita (ligada à Igreja Matriz de Santa Rita de Cássia), teve algumas disputas judiciais narradas pela imprensa, mas aparentemente não voltou a atuar musicalmente em público, vindo a falecer, depois de longa vida, em junho de 1989.

A ida de Maria Baylina para o Rio de Janeiro acabou se tornando um atrativo para a mãe, que também se estabeleceu na cidade, fixando residência no n. 6 da rua Fernando Osório, bairro do Flamengo, até sua morte (18 out. 1956), conforme se depreende da nota de falecimento assinada pelas duas filhas no jornal Diário de Notícias (1956): 


\section{Mercedes Garrido de Baylina}

(FALECIBIENTO)

Viuva Maria Baylina de Abreu, vluva Paquita Baylina de Sonza, dr. Luiz Augusto de Abrea e senhora, Rita Rigon Alabe, dr. Wilson Aldabe, seahora e filho, Ernesto Aldabe, senhora e filhos (ausentes), eumjeretn o doloroso dever do comenicar o falecimeato de sua querida mãe, avó e tia MERCEDES GARRIDO DE BAYLINA ocorrido ontem, convidam seus parentes e amigos para o seu sepultamento, suindo o féretro de sua residênia à rua Fernando Osorie $n^{\prime}$, hoje, sexta-feira, dia 19 , is 11 boras, para o Cemitério de Stao Jedo Batista.

Fig. 2. Nota de falecimento de Mercedes Garrido de Baylina. Fonte: (DIÁRIO DE NOTÍCIAS, 1956).

Como se observa, Paquita Baylina de Souza (nome de casada) também já era viúva em meados da década de 1950. Após a perda do marido, ela passará as décadas finais de sua vida no Rio de Janeiro, uma mudança certamente motivada pela presença da mãe e da irmã na cidade. Lá, tornou-se professora do célebre colégio Princesa Isabel Redentora, alocado no bairro de Botafogo, mas não encontramos notícias de que tenha atuado publicamente como instrumentista na capital carioca.

Porém, ao contrário da irmã, Paquita não casou logo nos anos iniciais da adolescência/juventude, o que a permitiu desempenhar atividades musicais por mais tempo no Rio Grande do Sul, sua terra natal. Entre 1910 e 1923 (ano do matrimônio e que, a par do que ocorrera com a irmã, encerra as suas aparições como musicista nos jornais da época), ela desenvolverá uma série de ações artísticas em Porto Alegre, seja coordenando e/ou participando de múltiplos eventos socioculturais, seja cantando e/ou tocando os instrumentos que dominava (sobretudo o violão) em palcos diversos.

O cartório porto-alegrense responsável pelo registro civil dos casamentos anota o enlace com o sr. Cezar Augusto de Souza em 23 de junho de 1923 (A FEDERAÇÃO, 1923a). Aparentemente, o casal não teve herdeiros, já que nenhuma das várias notas de falecimento publicadas após sua morte foi assinada por eventuais filhos. Paquita faleceu em abril de 1962, no Rio de Janeiro, motivando a comoção pública de familiares, amigas próximas e do colégio em que trabalhava, responsáveis pela veiculação de cinco notas de pesar em uma mesma edição do jornal Correio da Manhã (1962).

Não foi possível averiguar o ano exato em que Paquita deixa Porto Alegre em direção ao Rio de Janeiro, mas os movimentos dos portos anotados pelos jornais gaúchos indicam que ela conheceu a capital carioca já em meados de 1920, quando ainda morava em terras gaúchas (A FEDERAÇÃO, 1920j). Pouco mais de um ano depois, a musicista ainda faria outra viagem marítima, mais breve, integrando a comitiva do Destroyer Alagoas convidada para visitar as instalações da Companhia Minas de Carvão de São Jeronymo. 
Nesta última, Paquita foi responsável por animar a tripulação com números de canto: "A viagem decorreu por entre francas manifestações de alegria, improvisando-se, a bordo, uma festa, em que se salientou a senhorita Paquita Baylina, vocalizando varios trechos musicaes" (A FEDERAÇÃO, 1921L). Antes da mudança definitiva para o Rio, estes foram os dois únicos registros que encontramos de quaisquer viagens realizadas pela musicista para fora do Rio Grande do Sul.

Como frisamos, o casamento acabou interrompendo uma trajetória musical que tinha 13 anos de atividades ininterruptas, de 1910 a 1923․ É justamente neste período que constata-se a intensa participação de Paquita Baylina na cena musical de Porto Alegre, tornando-se uma das brasileiras pioneiras no domínio do "violão clássico", instrumento com o qual chegou a se apresentar diversas vezes em concertos coletivos realizados no Theatro São Pedro.

No Rio Grande do Sul, Paquita diversificou intensamente suas ações culturais desde muito cedo. Eis algumas de suas atividades mais recorrentes:

1) Sociedade carnavalesca Esmeralda: desde 1911, a musicista já participava das passeatas de gala e desfiles esmeraldinos, inclusive chegando a integrar comissões organizadoras e ocupar cargos diretivos no clube entre os anos de 1915 e 1921 (A FEDERAÇÃO, 1915b; 1921). Sua atuação na agremiação, portanto, perpassou uma década completa (1911-1921).

2) Organização de eventos socioculturais diversos: neste sentido, Paquita teve ação infrene, integrando comissões organizadoras de eventos com os mais variados propósitos: em outubro de 1916, colabora na homenagem (intitulada "batalha de flores") ao poeta Olavo Bilac realizada no jardim zoológico de Porto Alegre (A FEDERAÇÃO, 1916a); um ano depois, no contexto da 1a Guerra Mundial, desponta entre as responsáveis pelo Tea Concert em benefício das vítimas da invasão da Bélgica² (A FEDERAÇÃO, 1917b); já em junho de 1918, torna-se promotora do Festival de Caridade - ocorrido no palco do Theatro Guarany - , ação que visava angariar fundos para compra de cobertores e agasalhos destinados a pobres e moradores de rua, as maiores vítimas do rigoroso inverno sulista (A FEDERAÇÃO, 1918a).

Nos anos seguintes, dentre outras atividades, a musicista ainda ajudaria a organizar eventos beneficentes visando a construção de uma creche (A FEDERAÇÃO, 1919a) ou em favor da Santa Casa de Misericórdia (O EXEMPLO, 1919); participaria da coordenação de tendas em exposições de produtos (A FEDERAÇÃO, 1919b) ou de festas musicais

\footnotetext{
1 A intenção não é criticar levianamente a instituição do casamento ou uma eventual escolha de Paquita por ele (embora, naquele período, muitos enlaces eram realizados à revelia dos desejos das mulheres). 0 que se quer pontuar é que, independentemente de ser por imposição sociocultural ou escolha pessoal, o matrimônio representava para as mulheres, quase que invariavelmente, a abdicação de suas atividades profissionais e/ou públicas (foi assim com Paquita e com sua irmã), em uma herança que, ainda hoje, apresenta traços muito marcantes na organização social brasileira. São exemplos: associação de determinadas tarefas preponderantemente a homens ou mulheres; discrepância salarial no exercício de mesmas funções; reprodução da cultura e discursos machistas e/ou misóginos; o número significativo de feminicídios (vide o recente e brutal caso da promissora violonista Mayara Amaral), além do menor número de mulheres em cargos de liderança. No caso da música, em particular, basta observar como há um quantitativo significativamente menor de mulheres ocupando posições de destaque como compositoras, regentes, professoras e/ou instrumentistas.

2 Pouco mais de um mês depois, em 06 de dezembro de 1917, Paquita ainda participaria de outro "Chá-Concerto", desta vez "em favor dos refugiados do Veneto", no qual houve uma apresentação musical organizada por seu professor, o maestro João Corsi, além de Paquita também ter participado "da missão de servir o chá" (A FEDERAÇÃO, 1917c).
} 
promovidas pelo Centro Musical Porto-Alegrense (A FEDERAÇÃO, 1920a; 1920b); e, finalmente, em setembro de 1921, seria eleita uma das diretoras do "chá-tango" celebrado pelos alunos da faculdade de medicina (A FEDERAÇÃO, 1921b).

Assim, ainda que não contássemos com as suas atividades musicais (as mais recorrentes de sua trajetória), tais exemplos demonstram que Paquita ajudou a coordenar, em Porto Alegre, um número expressivo de eventos socioculturais nos anos compreendidos entre 1916 e 1921.

3) Solenidades da igreja católica: a musicista não foi desenvolta apenas no âmbito profano. Os ritos, festividades ou promoções ligadas à igreja católica também instigaram a sua participação em diversas oportunidades. Vale registrar que, a partir de 1921, Paquita foi dizimista regular da histórica igreja Nossa Senhora das Dores, a mais antiga da cidade ainda em pé, colaborando mensalmente para a realização de obras no templo ou em suas cercanias, tais como a construção de suas famosas escadarias (A FEDERAÇÃO, 1921c; 1921d; 1922).

Ainda nesta igreja, a musicista protagonizou uma miríade de momentos musicais relacionados ao calendário litúrgico da comunidade, quase sempre cantando a Ave-Maria. Assim foi na celebração do septenário de sua construção (A FEDERAÇÃO, 1921e; 1921f; 1921g; 1921h):

Festa das Dores- Foi a joven
cantora senhorita Paquita Baylina
que vocalizou a Ave-Maria na ce-
rimonia de hontem do septenario
da festa de $\mathrm{N}$. S. das Dores, e o
fez com muito gosto, eausando a
mais agradavel impressão geral.

Fig. 3. Menção à atuação de Paquita Baylina na festa do septenário da igreja N. S. das Dores. Fonte: (A FEDERAÇÃO, 1921h).

De fato, sua versão da Ave-Maria fez tanto sucesso que Paquita foi convidada a repeti-la em novenas, tríduos e festividades de pelo menos outras duas importantes igrejas porto-alegrenses: a matriz de Nossa Senhora da Conceição e a Catedral Metropolitana, em sequência de apresentações que entrecortaram os anos de 1921 a 1923 (A FEDERAÇÃO, 1921i; 1921j; 1922b; 1922c; 1922d; 1922e; 1923b). Contudo, após o casamento (ocorrido em junho de 1923, apenas um mês depois de sua última apresentação), não encontramos registros de quaisquer participações suas em solenidades religiosas do gênero.

4) Apresentações musicais: como acabamos de observar, Paquita parece ter sido uma personagem com significativa inserção na sociedade gaúcha, fato ratificado pela participação e/ou coordenação de blocos carnavalescos, solenidades da igreja católica e eventos socioculturais dos mais diversos.

Entretanto, o eixo de sua atuação social mais destacado e recorrente foi certamente o relativo à música. Multi-instrumentista (violão, piano, bandolim e canto), a mu- 
sicista protagonizou dezenas de apresentações em concertos coletivos realizados entre os anos de 1910 e 1923, tendo, em várias oportunidades, suas qualidades artísticas celebradas pela imprensa porto-alegrense. Pela importância, este aspecto de sua trajetória será abordado em tópico próprio, com ênfase em sua atuação como violonista.

\title{
2. Uma violonista em Porto Alegre no início do século XX
}

Na transição do século XIX para o XX, o ambiente para a atuação de violonistas mulheres no Rio Grande do Sul não era dos mais convidativos, embora uma janela tenha sido aberta com a difusão, no estado, de clubes musicais em torno dos quais se organizavam orquestras, coros e estudantinas abertas tanto a rapazes quanto senhoritas.

\begin{abstract}
Possivelmente um espaço híbrido e responsável por mediações entre estes dois mundos [o espaço doméstico e o espaço cênico-profissional] tenha sido aquele dos clubes musicais e sociais que mantinham orquestras, coros e estudantinas compostas por rapazes e senhoritas pertencentes as camadas mais privilegiadas da sociedade. Difundidos marcadamente nas últimas décadas do século XIX, tornaram-se espaços culturais onde as relações e considerações sobre artistas, repertório, instrumentos e práticas musicais foram hibridizando-se e adquirindo novas formas.

No contexto do Rio Grande do Sul, a cidade de Porto Alegre manteve clubes deste tipo, como por exemplo a Sociedade Filarmônica Porto-Alegrense e o Instituto Musical Porto-Alegrense, que mais tarde transformou-se no Clube Haydn.A cidade de Pelotas, importante centro cultural do período, também possuía entidades musicais de caráter recreativo que mantinham a mesma estrutura de orquestras, coros e estudantinas. Estas, por força da origem italiana de seus diretores, tinham necessariamente influência das estudantinas daquele país, seja no que tange às composições executadas, como aos arranjos ou à função social (PORTO; NOGUEIRA, 2007, p. 2).
\end{abstract}

Citando Corte Real (1984), as autoras acrescentam, na mesma página, que tais conjuntos instrumentais eram "compostos principalmente por violões e bandolins, provavelmente influenciados pelas estudantinas portuguesas". O principal instrumento de Paquita foi o violão; o de Maria Baylina, sua irmã, o bandolim. Parece natural que o caminho de entrada de ambas no cenário da música rio-grandense tenha sido justamente o dos clubes, estudantinas e/ou grupos musicais do gênero.

Contudo, Paquita parece ter alargado o rol de possibilidades de atuação do instrumento nestes ambientes, levando o violão a marcar presença também em espaços mais tradicionais da música de concerto. Empunhando-o, ela se tornou provavelmente a primeira mulher a solar peças do repertório clássico violonístico no histórico Theatro São Pedro. O evento, que também marca sua estreia nos palcos rio-grandenses, ocorreu no dia 26 de novembro de 1910, em concerto coletivo organizado pelo maestro Rodolpho Moriconi. Na ocasião, a musicista tocou a bela mazurca La Perezosa, composta por um dos pioneiros do violão de concerto na Argentina, o compositor-violonista Juan Alais (1844-1914). 


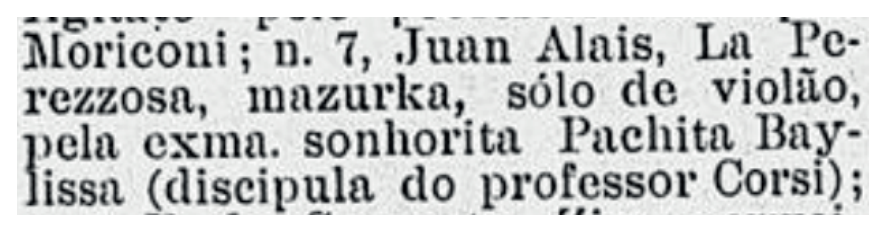

Fig. 4. Ao violão, Paquita estreia na cena musical porto-alegrense em concerto realizado no Theatro São Pedro. Fonte: (A FEDERAÇÃO, 1910).

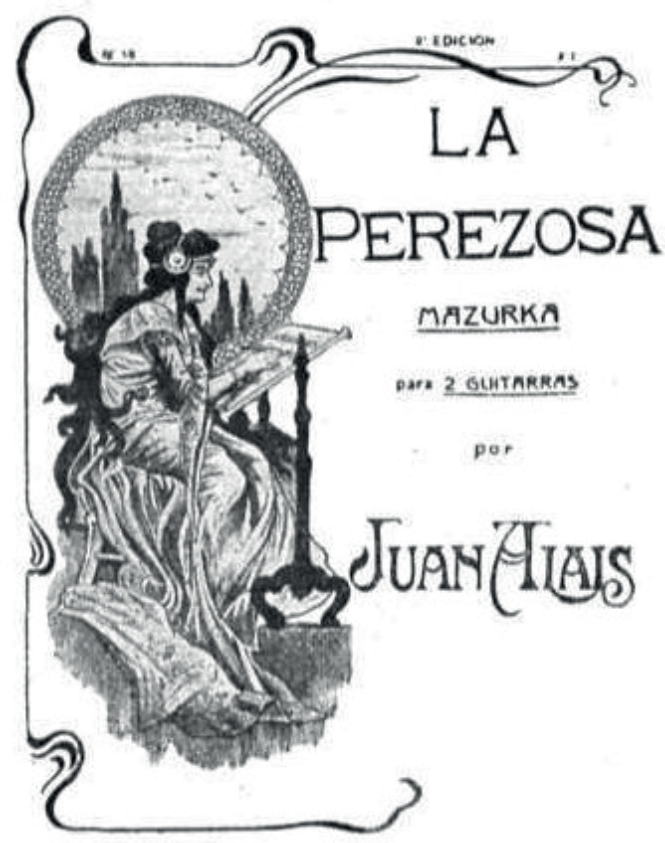

Fig. 5. Capa da versão para 2 violões da peça La Perezosa (Juan Alais), tocada na versão solo por Paquita Baylina no Theatro São Pedro em 28 de novembro de 1910. Fonte: acervo pessoal dos autores.

Note-se como a grafia do sobrenome de Paquita foi, na ocasião, registrada com pequena alteração (Baylissa ao invés de Baylina), o que corrobora o fato da artista estar em início de carreira, com seu nome ainda não reconhecido na cena musical porto-alegrense, um panorama que mudaria logo nos anos subsequentes.

Além disso, vale registrar a indicação nominal de seu professor, o maestro João Corsi, mestre do Instituto Musical, escola de música situada à rua Dr. Flores n. 1 E, e um dos personagens pioneiros no ensino de bandolim e violão em Porto Alegre. Corsi foi, por mais de uma década, o instrutor musical das irmãs Baylina: Maria (bandolim) e Paquita (violão). Não é à toa, portanto, que as duas eventualmente tenham se apresentado em duo, como no concerto coletivo realizado no Club Caixeiral em 20 de julho de 1912.

\section{Stephanie, Gahotte mandolin 0 violão executado pelas meninas Ma- ria e Pacca Baylina.}

Fig. 6. Excerto do programa executado no concerto realizado no Club Caixeral, em Porto Alegre, no dia 20 de julho de 1912. Na ocasião, Maria e Paquita Baylina tocaram bandolim e violão em duo. Fonte: (A FEDERAÇÃO, 1912). 
Aliás, através do Instituto Musical, foi João Corsi o responsável por organizar, em 22 de março de 1914, um concurso musical nos palcos do Club Caixeiral. O certame foi disputado por três de suas discípulas: Rola Müzell, ao bandolim; Maria Baylina, também ao bandolim; e Paquita Baylina, ao violão. Celebrado pela imprensa gaúcha, o evento contou com um júri de maestros e professores e distribuição de diplomas na premiação (A FEDERAÇÃO, 1914a).

No repertório, as concorrentes tinham que cumprir um programa que incluía solos em seus respectivos instrumentos e leituras à primeira vista no piano e em conjunto. Paquita tocou três partes de uma "Grande Sonata" do canônico compositor espanhol Fernando Sor (1778-1839). Pela descrição nominal dos movimentos apontada pelo jornal A Federação (1914a) na data do evento (andante, più mosso [que pode corresponder ao allegro] e minueto), a peça em questão é a Grande Sonata em dó maior op. 25, obra composta por Sor (cujo nome foi erroneamente grafado como "Shor") no ano de 1827.

Concarso do violẽo : senhorita

Paquita Baylina. Grande sonata. Frd. Shor; a) Andante, b) Piu mossb, c) Minuetto, d) Lcitura e transporte a primeira vista, (uma mu. sica de piano á escolha do jury),

e) Trecho de conjunto a primeira vista:

Fig. 7. Programa executado por Paquita Baylina no concurso musical realizado pelo Instituto Musical em 22 de março de 1914 , em Porto Alegre, no palco do Club Caixeiral. Fonte: (A FEDERAÇÃO, 1914a).

Dois dias depois de sua realização, o mesmo jornal publica uma resenha do evento intitulada "Concurso de Música". Nela, são destacadas não somente o programa das três participantes e a "seleta concorrência" de pessoas que assistiram as apresentações, mas também o desempenho de Paquita na Grand Sonata op. 25, de Sor. Segundo o crítico, a peça foi "admiravelmente executada ao violão" pela musicista (A FEDERAÇÃO, 1914b). 

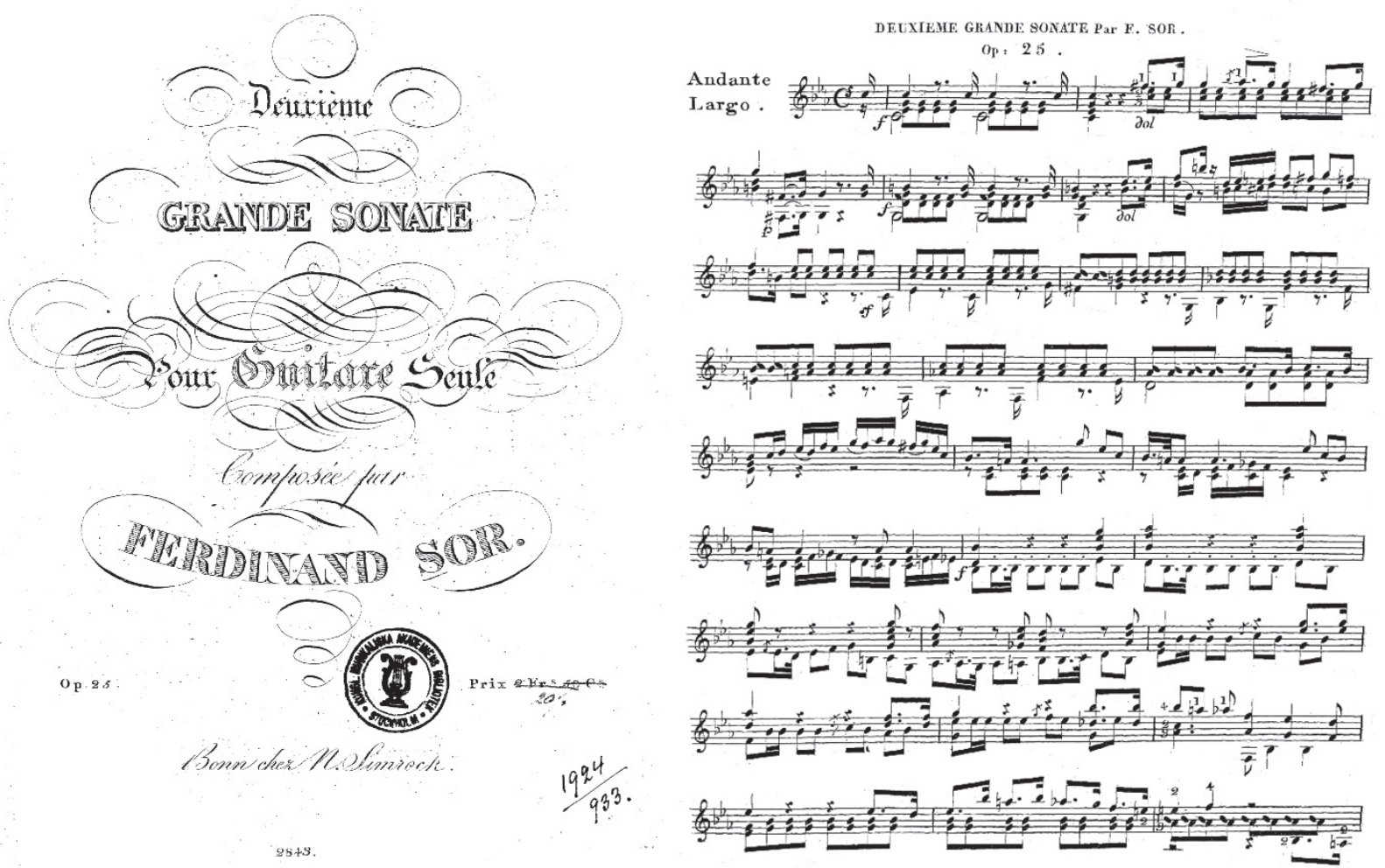

Fig. 8. Capa e $1^{\text {a }}$ página da Grand Sonata op. 25, de Fernando Sor, peça tocada por Paquita Baylina em concurso instrumental realizado em Porto Alegre no ano de 1914. Fonte: acervo pessoal dos autores.

De fato, a performance de Paquita Baylina foi de tal modo convincente que a levou a ser laureada com o primeiro prêmio no concurso (58 pontos), deixando o segundo lugar com a irmã Maria (56 pontos) e o terceiro com a mandolinista Roza Müzell (51 pontos). Vale destacar que o resultado do certame reverberou no Rio de Janeiro, em uma nota da Agência Americana reproduzida pela Gazeta de Notícias (1914).

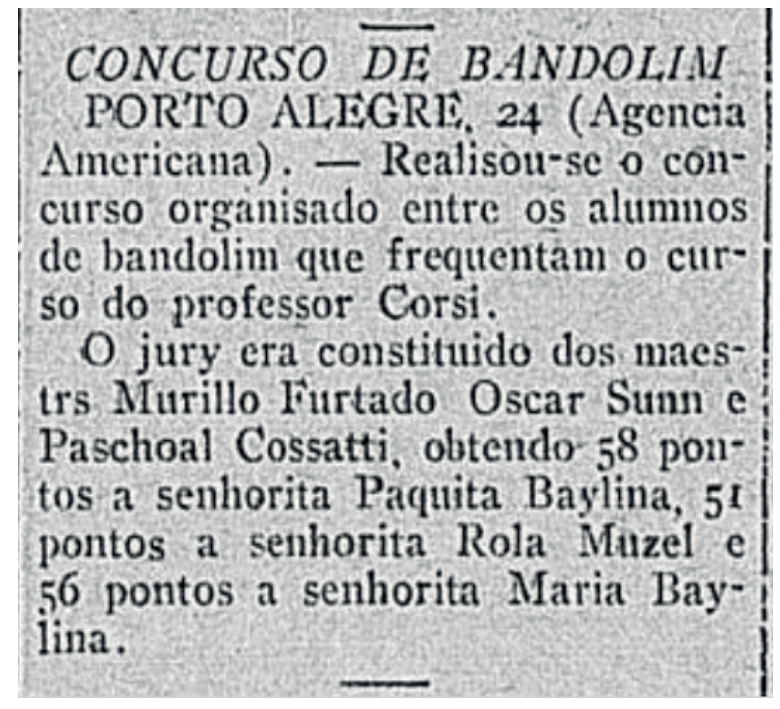

Fig. 9. Nota publicada pelo jornal carioca Gazeta de Notícias reverberando o resultado do concurso instrumental no qual Paquita Baylina sagrara-se vencedora. Fonte: (GAZETA DE NOTÍCIAS, 1914). 
Pode-se imaginar o grande impacto que o evento teve em terras gaúchas, tornando o trio de participantes mais conhecido na cena musical da cidade. Um indício do fato é que, pouco depois da realização do concurso, quadros artísticos com os perfis das concorrentes foram expostos na Tabacaria Central de Porto Alegre.

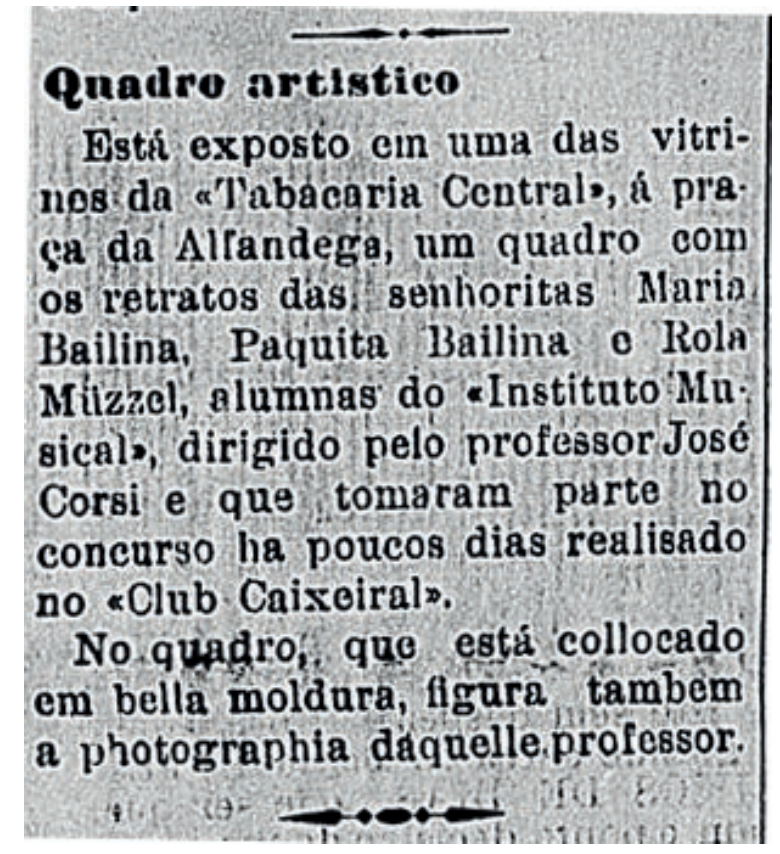

Fig. 10. Nota indicando que quadros artísticos das participantes do concurso, bem como de seu professor, José Corsi, estavam expostos na Tabacaria Central de Porto Alegre. Fonte: (A FEDERAÇÃO, 1914h).

Outro dado que registra a reverberação que a competição gerou foram os convites recebidos, pelas participantes, para integrar a programação musical de determinados eventos artísticos. Cerca de duas semanas após o certame, por exemplo, as três foram convidadas a tocar, juntas, no concerto vocal e instrumental concebido em homenagem ao aniversário natalício de Samuel Hanneman, o fundador da Faculdade de Medicina Homeopática da cidade.

Segundo a nota de divulgação publicada no jornal A Federação (1914c), a apresentação ocorreu no Theatro São Pedro e contou com um grupo "caprichosamente escoIhido dos melhores elementos da nossa cultura social". Dentre os convidados ilustres para a festa, constava o então "presidente do Estado", Borges de Medeiros. Na ocasião, o trio participou da segunda parte do espetáculo, protagonizando a peça Garota, de José Faini, maestro e compositor que havia sido um dos julgadores do concurso vencido por Paquita.

Ainda em 1914, o trio volta a se apresentar no concerto realizado em homenagem ao aniversário de sagração sacerdotal de d. João Becker, arcebispo metropolitano de Porto Alegre. O evento aconteceu no teatro do Centro Católico do Rio Grande do Sul, em 18 de setembro daquele ano, contando com diversas solenidades ao longo do dia. Pela noite, a programação musical encerrou as atividades com a apresentação de dez números musicais, dentre os quais despontava o trio de Paquita Baylina (violão), Maria 
Baylina (bandolim) e Roza Müzell (mandola) interpretando uma Serenata - Fantasia do compositor O. Munier (A FEDERAÇÃO, 1914d).

Além disso, na ocasião, as irmãs Baylina também tocaram peças solos para seus respectivos instrumentos: ao bandolim, Maria solou a Love Song, de C. Munter; ao violão, Paquita mais uma vez demonstrou o seu singular domínio instrumental ao programar a exigente Fantasia Original (1868), do compositor espanhol José Viñas (18231888), obra que emprega técnicas variadas e cujo tema principal se desdobra através de um trêmulo.
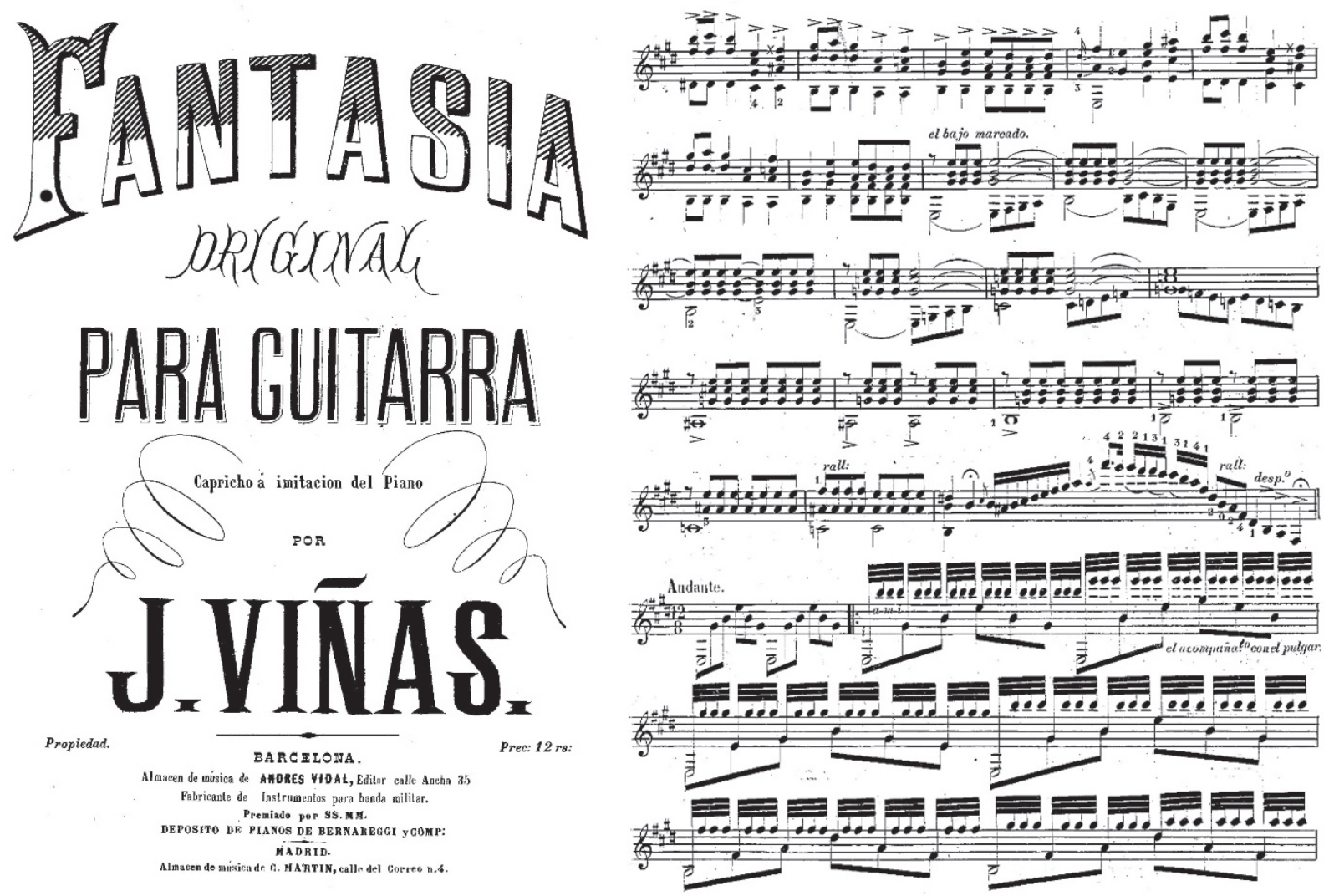

Fig. 11. Capa e início do tema com trêmulo da obra Fantasia Original - Capricho à imitação do Piano, de José Viñas. Fonte: acervo pessoal dos autores.

No dia seguinte à apresentação, uma resenha foi publicada no jornal A Federação (1914e) dando notícia de que "todas as executantes receberam prolongados aplausos", além de um buquê de flores oferecido pela organização do evento. A peça escolhida e a boa recepção do público são novos indícios de que Paquita não somente dominava o instrumento, mas também que, enquanto violonista, seu nome já alcançara certo prestígio e reconhecimento no circuito musical de Porto Alegre.

A partir de então, não é por acaso que a musicista passará a ser seguidamente referendada como uma distinta "professora" de música pela imprensa gaúcha: foi assim no concerto coletivo ocorrido no Theatro São Pedro em prol da Sociedade Dante Alighieri (A FEDERAÇÃO, 1914f; 1914g); em uma apresentação organizada pelo Comitato Italiano Pró-Pátria (A FEDERAÇÃO, 1915c); na inauguração do Theatro Infantil de Porto Alegre, 
então constituído por "cerca de vinte meninas das primeiras famílias desta cidade" ( $A$ FEDERAÇÃO, 1917d); em um festival de música promovido pelo Centro Católico (A FEDERAÇÃO, 1917e); no chá patriótico ocorrido no Club Caixeiral em benefício dos marinheiros brasileiros atuantes na Primeira Guerra Mundial (A FEDERAÇÃO, 1918b; 1918c; 1918d); e finalmente na série de concertos dirigidos pelo Centro Musical Porto-Alegrense (A FEDERAÇÃO, 1920c; 1920d).

Em todas estas apresentações, não é mencionado o nível de participação, instrumento musical ou repertório tocado por Paquita, mas é muito provável, pela proximidade das datas com outros eventos dos quais a musicista participou, que o violão tenha sido empunhado em pelo menos algumas das performances.

\section{Canto e violão}

A atuação de Paquita Baylina ao violão foi bastante diversificada, incluindo trabalhos como professora, solista, camerista e acompanhante de canções que, muitas das vezes, eram cantadas por ela própria. A partir de meados de 1918, esta última faceta ganha contornos mais nítidos em sua trajetória, sobretudo através da participação em diversos acontecimentos musicais nos quais a musicista encarna essa dupla condição de cantora e violonista acompanhante.

O primeiro evento do gênero foi o "concerto patriótico" realizado em 26 de agosto de 1918, no Theatro São Pedro, em outro espetáculo beneficente às famílias dos marinheiros brasileiros atuantes na Primeira Guerra Mundial (1914-1918). Com o recinto cheio e sob a presença de autoridades brasileiras e estrangeiras, Paquita, uma vez mais, brilhou no principal palco da cena musical porto-alegrense:

[...] O concerto realizou-se hontem [26 de agosto de 1918], no theatro S. Pedro, com um brilhantismo desusado e com a presença do que a sociedade de Porto Alegre tem de mais fino e mais culto.

O theatro achava-se completamente cheio, estando o camarote presidencial occupado pelo dr. Borges de Medeiros e sua exma. família e outros tomados pelo barão de Vayavière, consul da França; dr. T. C. Dillon, consul de S. M. Britannica; dr. Oscar Deffaminis, consul geral do Uruguay; dr. Arnando Fonseca, consul de Portugal; e sr. Alexandre Boltini, consul da Argentina, além de outras autoridades civis e militares.

[...] A senhorita Paquita Baylina cantou, acompanhada de violão, varias canções, entre as quaes o 'cigarro do soldado', adaptada ao soldado brasileiro.

Este número foi bastante applaudido, sendo, tambem, bisado [...] (A FEDERAÇÃO, 1918e).

Poucos dias depois, em 12 de setembro de 1918, a musicista volta a se apresentar, desta vez em um chá-concerto realizado nos salões do Club do Commercio em benefício da Cruz Vermelha dos países aliados: "[...] II parte - Canção, pela senhorita Paquita Baylina" (A FEDERAÇÃO, 1918f). Em fevereiro do ano seguinte, será a vez de estrear nos palcos do cineteatro Thalia, em evento beneficente "aos compatriotas do Ceará" afetados pela seca. Na ocasião, uma "enchente colossal" de pessoas se reuniu para assistir à programação musical, com um dos números encabeçados pelo "canto à guitarra" de 
Paquita Baylina (A FEDERAÇÃO, 1919c).

Entretanto, foi no retorno ao palco do Theatro São Pedro que Paquita, uma vez mais, protagoniza um dos momentos mais importantes de sua trajetória artística, integrando o programa do festival lítero-artístico ocorrido em 14 de fevereiro de 1920. A importância do espetáculo pode ser auferida pela pompa e o destaque que o jornal $\mathrm{A}$ Federação (1920e) dedicou à divulgação do evento:

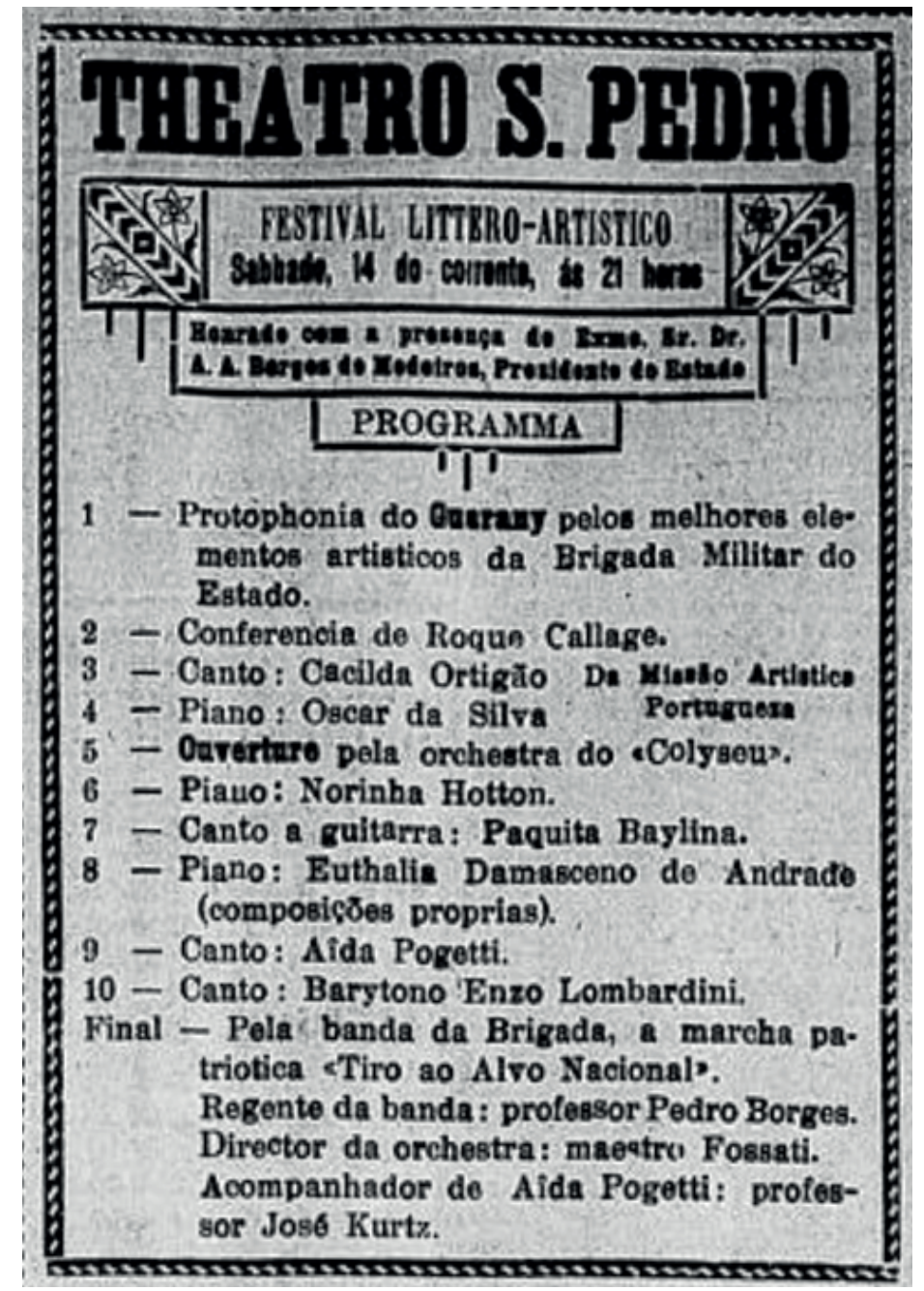

Fig. 12. Programa levado a cabo no festival lítero-musical ocorrido no Theatro São Pedro em 14 de fevereiro de 1920. A divulga-

ção foi literalmente repetida na edição seguinte do jornal A Federação. Fonte: (A FEDERAÇÃO 1920e; 1920f).

Como se nota, Paquita foi a responsável pelo sétimo número do programa, novamente apresentando-se na dupla função de cantora e acompanhante ao violão. Sua performance foi destacada na crítica publicada pela imprensa gaúcha dois dias após o evento, que, de forma geral, classificou o acontecimento como "interessante", "chique" e repleto "de um público de escol": "7 - Paquita Baylina, encantadora à guitarra, na graça insinuante dos seus maviosos descantes" (A FEDERAÇÃO, 1920g).

Este evento havia sido engendrado para ajudar as vítimas atingidas pela forte seca que assolava o território cearense. Pelo mesmo motivo, um novo concerto foi organizado cerca de dois meses e meio depois (05 mai. 1920), novamente contando com a pre- 
sença de Paquita Baylina entre as (os) artistas convidadas (os) (A FEDERAÇÃO, 1920h). Dentre os registros que coletamos, esta seria a sexta apresentação de Paquita nos palcos do célebre Theatro São Pedro.

Ainda na função de cantora-violonista acompanhante, a musicista voltará ao Club Caixeiral para participar da $2^{\underline{a}}$ Exposição de Trabalhos Manuais Femininos, uma iniciativa promovida pela Associação Obras de Santa Isabel. O evento consistia em uma exposição cujos trabalhos eram expostos em mostruários/estantes, concorrendo entre si nas diferentes categorias de premiações. Dispersa em vários dias, a programação incluía sessões musicais pela noite. Paquita participou do concerto vocal e instrumental realizado no dia 14 de maio de 1920, novamente performando "canções ao violão" (A FEDERAÇÃO, 1920i).

Em síntese, vale destacar que Paquita teve uma dupla atuação destacável em relação ao violão no Rio Grande do Sul (e, de forma geral, também no Brasil): como solista, sendo provavelmente a primeira mulher a apresentar peças do repertório clássico nos principais teatros da cidade; e como cantora-violonista acompanhante, condição na qual também foi uma personagem desbravadora em terras gaúchas.

\section{A relação com o violonista cego Levino Albano da Conceição}

A proximidade de Paquita com o violão ainda seria ratificada pela inesperada relação com o compositor-violonista cego Levino Albano da Conceição (1883-1955), um dos principais personagens do instrumento no Brasil ao longo da primeira metade do século $X X^{3}$.

Nascido em Cuiabá (MT) e radicado boa parte de sua vida no Rio de Janeiro (onde chegou em 1903), Levino foi, neste período, um dos mais decisivos divulgadores do violão solista em território brasileiro, tendo suas apresentações sido registradas por periódicos de diversos estados: Mato Grosso, Rio de Janeiro, Rio Grande do Sul, Florianópolis, São Paulo, além de países vizinhos como Paraguai e Uruguai, um périplo impressionante para um violonista que convivia com os diários desafios de locomoção que a cegueira lhe impunha. Se hoje é difícil imaginar o feito, imagine-se as dificuldades enfrentadas pelo músico há mais de cem anos, em um período no qual as viagens eram mais demoradas e as condições de acessibilidade dos portadores de necessidades especiais aos espaços públicos e privados eram ainda mais precárias.

Em relação à difusão do violão solista pelos recantos do Brasil, podemos comparar (guardadas as devidas proporções) a jornada empreendida por Levino com aquela empreendida pelo célebre Agustín Barrios (1885-1944), compositor-violonista paraguaio que se embrenhou nos interiores do Brasil para divulgar o seu repertório solo no instrumento. Neste sentido, a passagem pelo Rio Grande do Sul foi uma das mais significativas para Levino: seja por abarcar integralmente a década compreendida entre os anos

\footnotetext{
3 Sobre este personagem, cf. o verbete escrito por Jorge Carvalho de Mello para o dicionário online do Acervo Digital do Violão Brasileiro. Disponível em: http://www.violaobrasileiro.com/dicionario/visualizar/levino-albano-da-conceicaoAcesso em 16 mar. 2018, às 18:50 h.
} 
de 1913 e 1923, ínterim no qual o músico realizou dezenas de apresentações em Porto Alegre e em diversas cidades do interior gaúcho; seja pelo significativo prestígio e reconhecimento que ele alcançou no ambiente sociocultural do estado.

Por ora, não é nosso objetivo esmiuçar pormenorizadamente a longa estada de Levino no Rio Grande do Sul (algo que desenvolveremos em um estudo específico), apenas destacar o aspecto capital para o estabelecimento do contato com Paquita Baylina, qual seja a sua singular atuação, na região, como professor de violão.

Não se sabe ao certo em que circunstâncias estes dois personagens se conheceram e estreitaram relações, mas o contato certamente foi facilitado pelo fato de ambos terem se tornado figuras amplamente reconhecidas na cena musical de Porto Alegre em meados da década de 1910.

Tampouco se tem notícias precisas de quando começaram as aulas, mas há alguns indícios concretos de que a relação entre o mestre e a sua discípula foi afetiva e duradoura: inicialmente, vale registrar que Levino chegou a dedicar peças de sua autoria à Paquita (conforme veremos a seguir); depois, pontue-se a participação ativa da musicista em apresentações do violonista cego realizadas entre os anos de 1917 e 1919, pelo menos.

O primeiro desses encontros anotados pela imprensa gaúcha data de fevereiro de 1917, quando o jornal A Federação (1917f) informa que "o guitarrista cego Levino Albano da Conceição realizará um grande concerto, no salão do Palacete Rocco, dedicado ao comércio porto-alegrense", acrescentando ainda que:

Prestarão o seu valioso concurso a essa festa de arte a galante conterrânea Anita Paquita Baylina, que é, além de eximia pianista, intelligente guitarrista.

Anita Baylina far-se-á ouvir, ao piano, tocando a Mazurka n. 2, do concerto (Kodá). [...] (A FEDERAÇÃO, 1917f).

Curiosamente, é como pianista que Paquita participará do concerto de violão de seu professor. Além de solar a Mazurca n. 2, de Kodá, a musicista ainda seria a responsável por acompanhar, ao piano, duas peças de flauta na sequência do programa.

Outros dois fatores ainda se destacam na passagem: a indicação do nome "Anita" em sua assinatura (Anita Paquita Baylina), única vez em que essa referência é utilizada (não foi repetida nem mesmo quando, anos depois, o seu casamento foi anunciado), o que eventualmente pode se configurar em um erro de impressão e/ou falha do redator; e o fato da musicista ser apresentada como "exímia" ao piano e "inteligente" ao violão. Abre-se, portanto, uma perspectiva de sua atuação musical que ainda não havia se deflagrado: o domínio de instrumentos variados.

Três dias depois, em 06 de fevereiro de 1917, a imprensa frisa que havia uma "grande animação entre a elite social" e destaca a presença de Paquita nos seguintes termos: "a galante senhorita Paquita Baylina, apreciada musicista, far-se-á aplaudir tocando diversas peças ao piano" (A FEDERAÇÃO, 1917g). O mesmo jornal seguiu anunciando o concerto nos dias seguintes, culminando na divulgação ocorrida no dia 08 de fevereiro de 1917, data do espetáculo: 


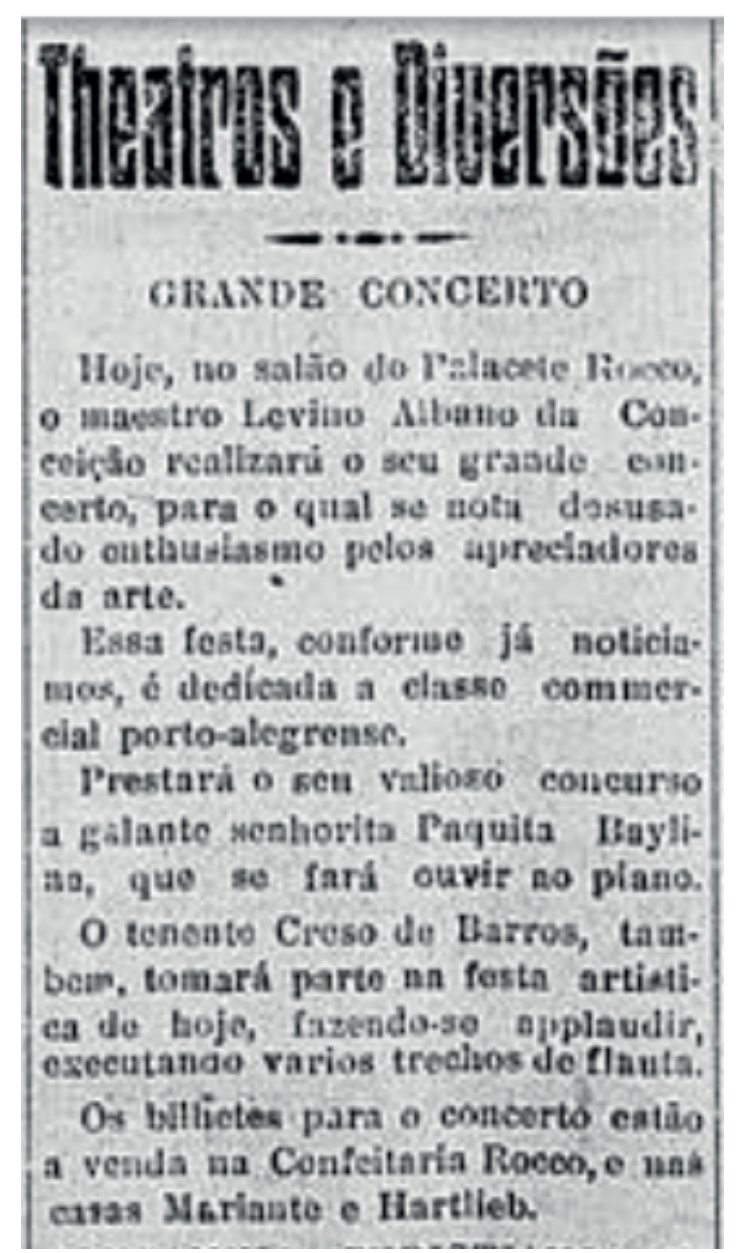

Fig. 13. Divulgação do concerto do violonista Levino Albano da Conceição no Palacete Rocco, com a participação de Paquita Baylina ao piano. Fonte: (A FEDERAÇÃO, 1917i; 1917h).

No dia seguinte, a crítica do concerto pontuou não somente a habilidade de Levino ao executar "difíceis trechos de música no violão e no violoncelo", mas também o "valioso concurso" oferecido à "festa de arte pela galante musicista senhorita Paquita Baylina, que foi aplaudidíssima" (A FEDERAÇÃO, 1917j).

Mas esta não foi a única participação de Paquita em um concerto protagonizado por Levino. A experiência se repetiria por duas vezes no ano de 1919, sendo que, na primeira delas, realizada no dia 05 de fevereiro no palco do Theatro São Pedro, a musicista contribuiu apenas na organização.

Amplamente coberto pela imprensa, o evento foi classificado como "o festival artístico do exímio guitarrista cego Levino da Conceição". Ao publicar uma longa e detalhada crítica da apresentação (com comentários sobre cada número musical), o jornal O Exemplo (1919b) ainda sublinha que o artista gozava de muitas "amizades e elevada consideração" tanto na capital quanto no interior do estado. Especificamente sobre o programa desempenhado e o papel exercido por Paquita na ocasião, teceu os seguintes comentários: 


\begin{abstract}
O ilustre concertista teve a nímia gentileza de dedicar essa audição artística à imprensa local, e o programma que organizou foi dos mais attrahentes, merecendo de sua parte integral execução, tanto do posto de vista mecânico como do elevado sentimento que sua alma de eleito aos mysterios do rythmo, sabe imprimir ás variadas e complexas tonalidades do som. [...]

O festival de Levino da Conceição foi magistral na delicadeza da arte e bello extremamente bello pelo sentimento que lhe inspirou a sua alma de eleito ás mais emocionaes vibrações da musica.

A plateia do S. Pedro estava repleta do que há de mais selecto na esfera dos admiradores da arte.

Encarregou-se da passagem da casa a distincta virtuose de guitarra, bandolim e piano, demoiselle Baylina em companhia de uma sua amiguinha cujo nome não nos ocorre, concorrendo esse delicado gesto para dar ao festival de Levino a nota chic e elegante no que concerne à presença do bello sexo [...] (O EXEMPLO, 1919b, grifo nosso).
\end{abstract}

A passagem é reveladora em duplo sentido:

1) Inicialmente, porque atesta que uma apresentação dedicada integralmente a um repertório para violão solo era capaz de encher o principal teatro da capital gaúcha e ser saudada com entusiasmo pelo público e a crítica impressa. A par de seu talento e trabalho sólido, é possível que a condição física de Levino e, sobretudo, as suas habilidades para transitar nos círculos da alta sociedade e da imprensa também tenham se configurado em atrativos extras para o sucesso e reverberação de suas performances.

Mas o fato é que o instrumento estava ali, ovacionado no palco principal da cidade, revelando, talvez, que outros usos e discursos em torno de si aconteciam, o que possivelmente acresce, neste período, outra narrativa àquela que crava o violão como objeto estigmatizado e não pertencente aos ambientes da música de concerto. No Rio Grande do Sul, pelo contrário, as atuações de Levino Albano da Conceição, envi, Paquita Baylina, dentre outros, demonstram que o violão se inseria em contextos socioculturais diversos já em princípios do século $X X$, incluindo a presença em salões e teatros mais vinculados a uma tradição musical "clássica".

2) Depois, por se referir a Paquita Baylina como uma "distinta virtuose" em três instrumentos musicais: o violão, o piano e o bandolim. O fato do articulista destacá-la de tal modo - em um momento no qual a musicista não atuava artisticamente e era apenas responsável por "passar o chapéu" entre o público e convidados presentes ao fim da apresentação - demonstra o notório reconhecimento que ela detinha no cenário musical de Porto Alegre, suposição reiterada pela constatação de que o mesmo redator sequer recordava o nome da amiga que, naquela ocasião, ajudou-a "na passagem da casa".

A estreita relação entre Paquita Baylina e Levino Albano da Conceição seria ainda reiterada meses depois, em novo concerto no Theatro São Pedro protagonizado pelo músico cego e alguns convidados: os professores e irmãos João e José Kurtz e o seu discípulo de violão Carlos Lemos. Ocorrida no dia 20 de agosto de 1919, a apresentação teve, na segunda parte do programa, a audição de uma peça de Levino interpretada pelo próprio e que trazia o seguinte oferecimento: "Romance Voir et Aimer [Ver e Amar], dedicado à sua discípula senhorita Paquita Baylina (violão)" (A FEDERAÇÃO, 1919d). 
A dedicatória e o título da obra indicam que a relação entre o professor e a aluna foi, de fato, importante para ambos: Paquita chegou a ajudar o mestre em algumas das apresentações que realizou em Porto Alegre, ora tocando (piano!) e ora colaborando na organização; Levino, por sua vez, cristalizou o carinho e admiração que sentia pela discípula dedicando-lhe nominalmente uma das músicas que compôs e tocou publicamente no palco do Theatro São Pedro.

\section{Outros instrumentos}

A apresentação como pianista em um concerto do violonista cego Levino Albano da Conceição nos remete à faceta multi-instrumentista de Paquita Baylina. Apesar de sua atuação no violão - seja como solista ou acompanhante - ter sido a mais recorrente e registrada, por vezes a imprensa local ratifica este domínio exercido por ela em outros instrumentos musicais.

Já em janeiro de 1915, por exemplo, o jornal A Federação (1915d) revela que Paquita participou do sarau musical organizado pelo famoso violoncelista Paschoal Fossati no palco do Club Caixeiral. Ao lado de sua irmã, Maria Baylina, a musicista protagonizou uma peça para bandolim e piano na segunda parte do programa: a 2ª Mazurca-Fantasia op. 273, do bandolinista italiano Carlo Munier (1859-1911), curiosamente um compositor que escreveu boa parte de suas obras para bandolim e violão.

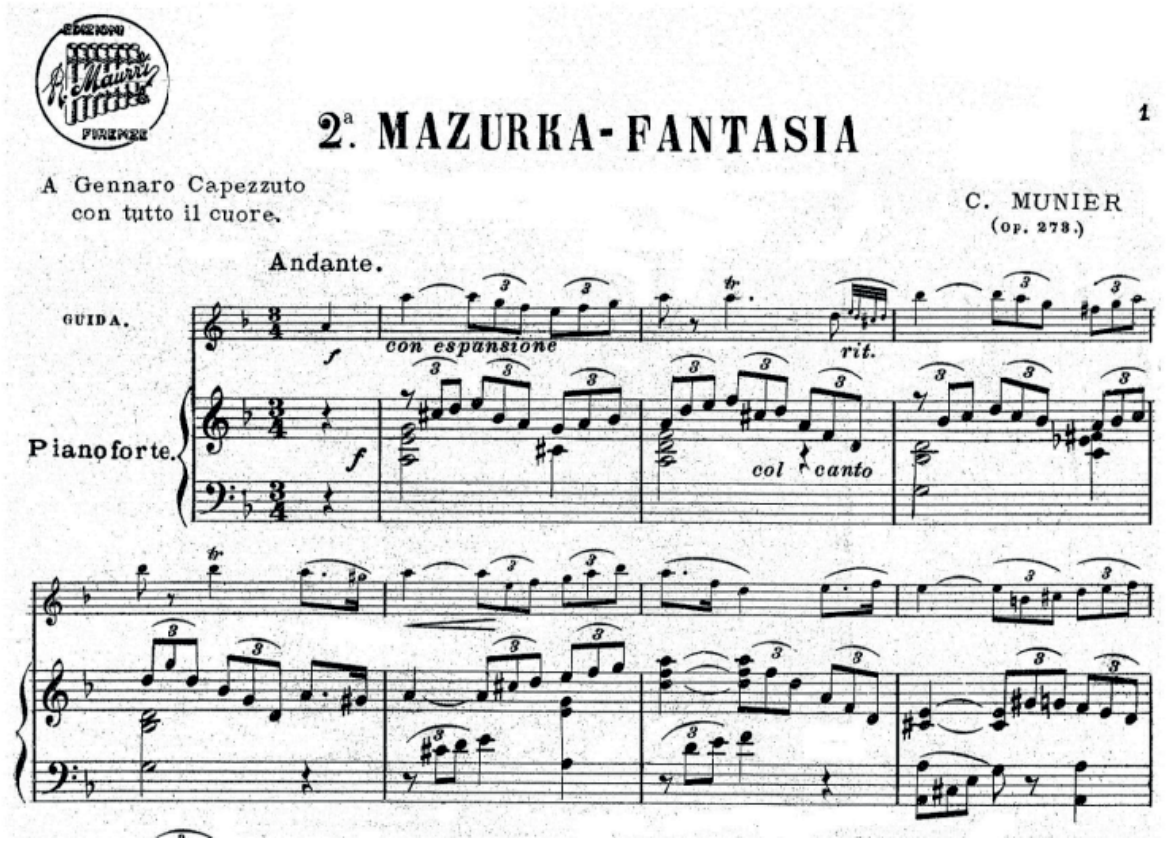

Fig. 14. Compassos iniciais da 2a Mazurca-Fantasia, de Carlo Munier, peça tocada por Maria Baylina (bandolim) e Paquita Baylina (piano) no sarau musical realizado em 17 de janeiro de 1915 no Club Caixeiral. Fonte: IMSLP4.

\footnotetext{
4 Disponível em: http://imslp.org/wiki/Mazurka-Fantasia_No.2\%2C_Op.273_(Munier\%2C_Carlo) Acesso: 18 mar. 2018, às 15:54
} 
As apresentações ao piano, contudo, não foram as únicas que se somaram às suas performances realizadas ao violão. Como vimos no tópico anterior, Paquita atuou diversas vezes como cantora - notadamente com a sua versão da Ave-Maria - em solenidades e/ou festividades relativas à igreja católica. A musicista, inclusive, chegou a desenvolver estudos formais de canto no Instituto Musical de Porto Alegre, onde integrou a classe da professora Olga Mussulin e teve um dos melhores desempenhos dentre as alunas inscritas na turma.

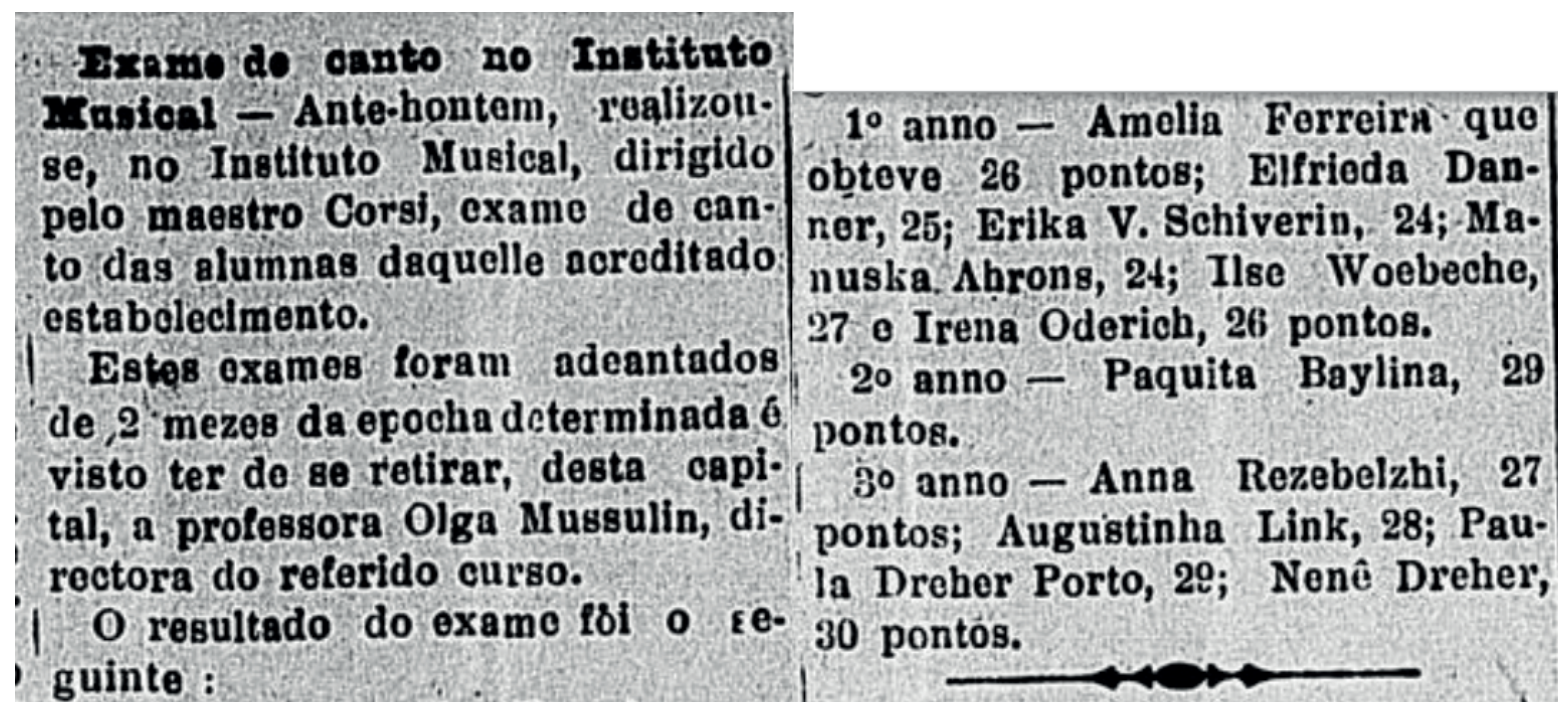

Fig. 15. Notas do exame das alunas de canto do Instituto Musical de Porto Alegre publicadas na imprensa gaúcha em 03 de outubro de 1917. Paquita Baylina tirou 29 pontos (em 30 possíveis), alcançando a $2^{a}$ maior pontuação da classe. Fonte: (A FEDERA-

ÇÃO, 1917l; 1917m).

Ainda como desdobramento de sua atividade como cantora, Paquita também atuou eventualmente em grupos corais, como aquele que participou do portentoso concerto realizado no Theatro São Pedro pela Associação Beneficente Damas de Caridade. Ocorrido em 19 de novembro de 1917, o espetáculo contou com orquestra, cameristas, solistas e um grande coro feminino a três vozes. Com a musicista no elenco, este último grupo protagonizou a peça Pardon Breton, da compositora e pianista francesa Cécile Chaminade (1857-1944) (A FEDERAÇÃO, 1917n).

\section{Casamento e interrupção das atividades musicais}

Como reverberação de sua notável inserção na cena musical gaúcha, Paquita logo se tornou figura reconhecida no bojo social de Porto Alegre. Alguns fatos extramusicais corroboram a sentença: em abril de 1914, um quadro com o seu perfil foi exposto na Tabacaria Central da cidade (A FEDERAÇÃO, 1914h); em fevereiro de 1918, seria a vez do número 28 da revista local Kodak estampar um de seus retratos em suas páginas ( $A$ FEDERAÇÃO, 1918g). Neste mesmo ano, a Revista Acadêmica a torna uma das dedicatárias do festival que organizou no palco do luxuoso Cineteatro Guarany (A FEDERAÇÃO, 
1918h). Não obstante, a musicista chegou mesmo a ter uma nota de aniversário individual publicada nas colunas sociais do jornal A Federação (1917a):

\section{Faz annos hoje a senborita lai- quita Baylina, fillua da exma. sra. d. Mercedes Baylina.}

Fig. 16. Nota pelo aniversário de Paquita Baylina publicada no jornal A Federação em 18 de abril de 1917. Fonte: (A FEDERAÇÃO,

1917a).

Tais fatores são traços inegáveis do prestígio que Paquita alcançou logo nos primeiros anos da juventude. Além disso, os jornais gaúchos também revelam que a musicista pertencia à "alta sociedade" porto-alegrense, circulando e articulando-se em alguns de seus espaços mais característicos: em 14 de maio de 1914, por exemplo, a récita do ator Carlos Abreu no Theatro São Pedro é oferecida "em honra da elite de Porto Alegre", então "dignamente representada" por uma plêiade de "excelentíssimas senhoritas", dentre as quais Paquita foi nominalmente mencionada (A FEDERAÇÃO, 1914i) em outro caso, ao ser anunciada a sua filiação como sócia do Club Caixeiral (onde se apresentou algumas vezes), Baylina seria distinguida como uma "distinta" senhorita (A FEDERAÇÃO, 1915e).

Neste sentido, podemos dizer que Paquita reflete, pelo menos em parte, uma tradição cultural que remete ao início do século XIX, quando a institucionalização da educação promovida, sobretudo após a chegada da família real portuguesa (1808), insere a música no rol das atividades ("prendas") que se esperava que "as moças de boa estirpe" dominassem (cf. AMORIM, 2017), ao lado de saberes/fazeres como gramática, línguas estrangeiras e manejos diversos de uma casa.

Assim, o domínio da teoria, do canto e dos instrumentos musicais representava, para as mulheres, não somente um caminho para a inserção em dinâmicas socioculturais diversas (como participações em eventos, concertos, associações, sociedades, etc.), mas também condição sine qua non para o sentimento de pertença e aceitação dentro da então propalada "escol de elite".

$\mathrm{Na}$ tradição cultural da época (e que infelizmente ainda sustenta resquícios socioculturais nos dias de hoje), a música tornava-se, em boa parte dos casos, uma poderosa vitrine para suas praticantes, dando-lhes visibilidade e posicionando-as em um lugar "privilegiado" para a negociação de bons contratos de casamentos, muitas vezes acordados à revelia de suas vontades (parece ter sido o caso de Maria Baylina, irmã de Paquita).

\footnotetext{
50 mesmo ator Carlos Abreu voltaria a incluir Paquita dentre as senhoritas da elite homenageadas em outro evento que realizou mais de dois anos depois, em 13 de novembro de 1916, no Petit-Casino da cidade: "elegantíssima Matinée Rose, em honra da Elite de Porto Alegre, dignamente representada pelas Exmas. Srtas [...] Paquita Baylina" (A FEDERAÇÃO, 1916b).
} 
Para alcançar este propósito, havia a projeção de uma imagem idealizada sobre as mulheres: aliar a formosura inerente do "belo sexo" a uma formação cultural básica e direcionada para suportar (em duplo sentido) a família e os cuidados da casa. Anotados pelos jornais da época, alguns discursos em torno de Paquita nos dão uma noção precisa do lugar que se esperava que uma mulher ocupasse. Em janeiro de 1919, por exemplo, a musicista recebe uma "homenagem" ao ser incluída no concurso de beleza que pretendia eleger as mais formosas torcedoras dentre os principais times brasileiros de futebol. Na ocasião, representando o Grêmio Foot-ball Porto Alegrense, Paquita chegou a receber dois votos (VIDA SPORTIVA, 1919). O prêmio? A publicação de uma fotografia "em ponto grande" nas páginas da revista promotora.

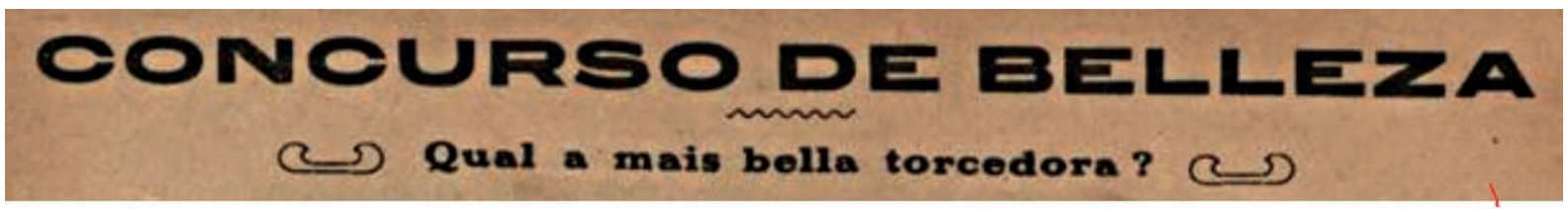

-Vida Sportivas querendo homenagear suas gentis leitoras, resolveu abrir um interessantissimo concurso de belleza para saber qual a mais bella torcedora.

As torcedoras residentes nos Estados, tambem entram em concurso.

Para que os votos sejam apurados basta cortar o keoupon * junto e envial-o d́ esta Redação, com os seguintes dizeres: *Vida Sportiva» Avenida Mem de Sá, 149 Rio - *Concurso de Belleza».

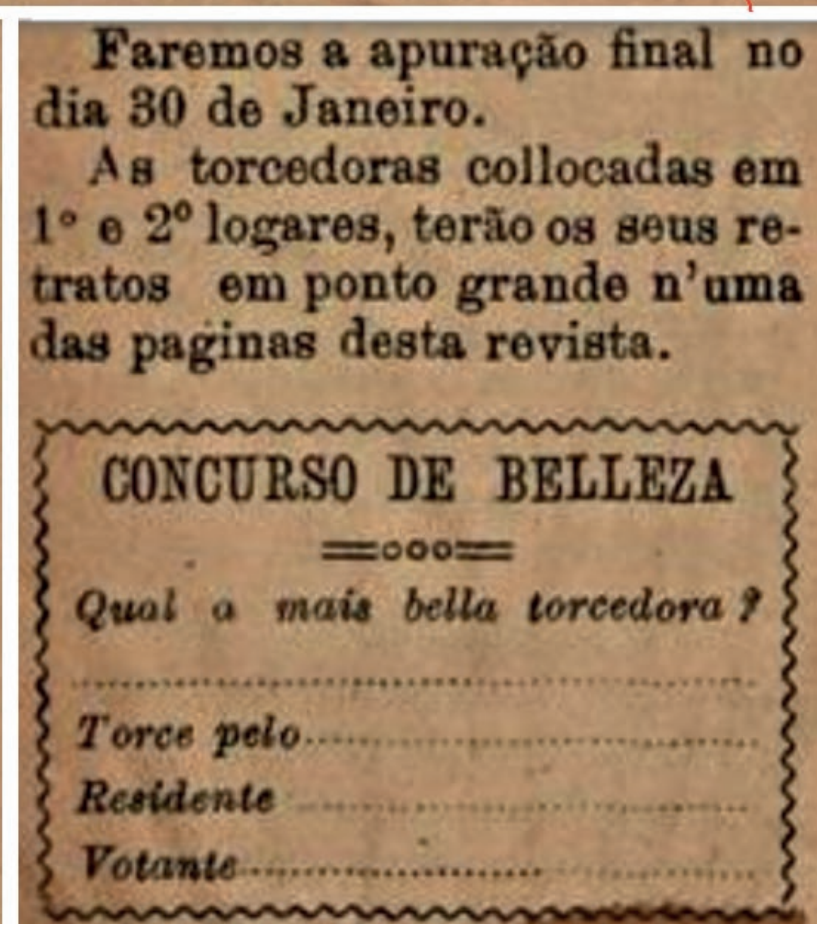

Fig. 17. Regulamento do concurso de beleza realizado com o objetivo de escolher, em 1919, a mais bela torcedora dentre os times brasileiros de futebol. A prática subsiste ainda hoje, em competição conhecida como "A Musa do Brasileirão"6. Fonte: (VIDA

Contudo, nenhuma projeção de imagem sobre Paquita é tão forte quanto aquela que emerge de uma troca de cartas realizada entre a musicista e um admirador baiano (ou radicado na Bahia) em meados de 1919. Aparentemente, ambos haviam sido tomados por uma paixão à distância, o que motivou o homem a responder uma das missivas

6 Disponivel em: http://www.musadastorcidas.com/

Acesso em 19 mar. 2018, às 16:19 h. 
de sua musa publicamente, em uma das edições da revista de variedades Bahia Illustrada. Intitulada "Vida do Sentimento", a carta apresenta, dentre uma série de declarações apaixonadas, os seguintes auto-questionamentos ao lado da foto de Paquita:

Aqui está o teu retrato. Estarei deante de um equívoco? Seja-o. Já o amo. O amor é assim. Espontaneo. Não há nada mais livre que uma paixão, quando verdadeira. E um grande coração tem o direito de amar. És bella? Não o serias, jamais, sem a paixão e a graça. Não há belleza sem amor [...] (BAHIA ILLUSTRADA, 1919).

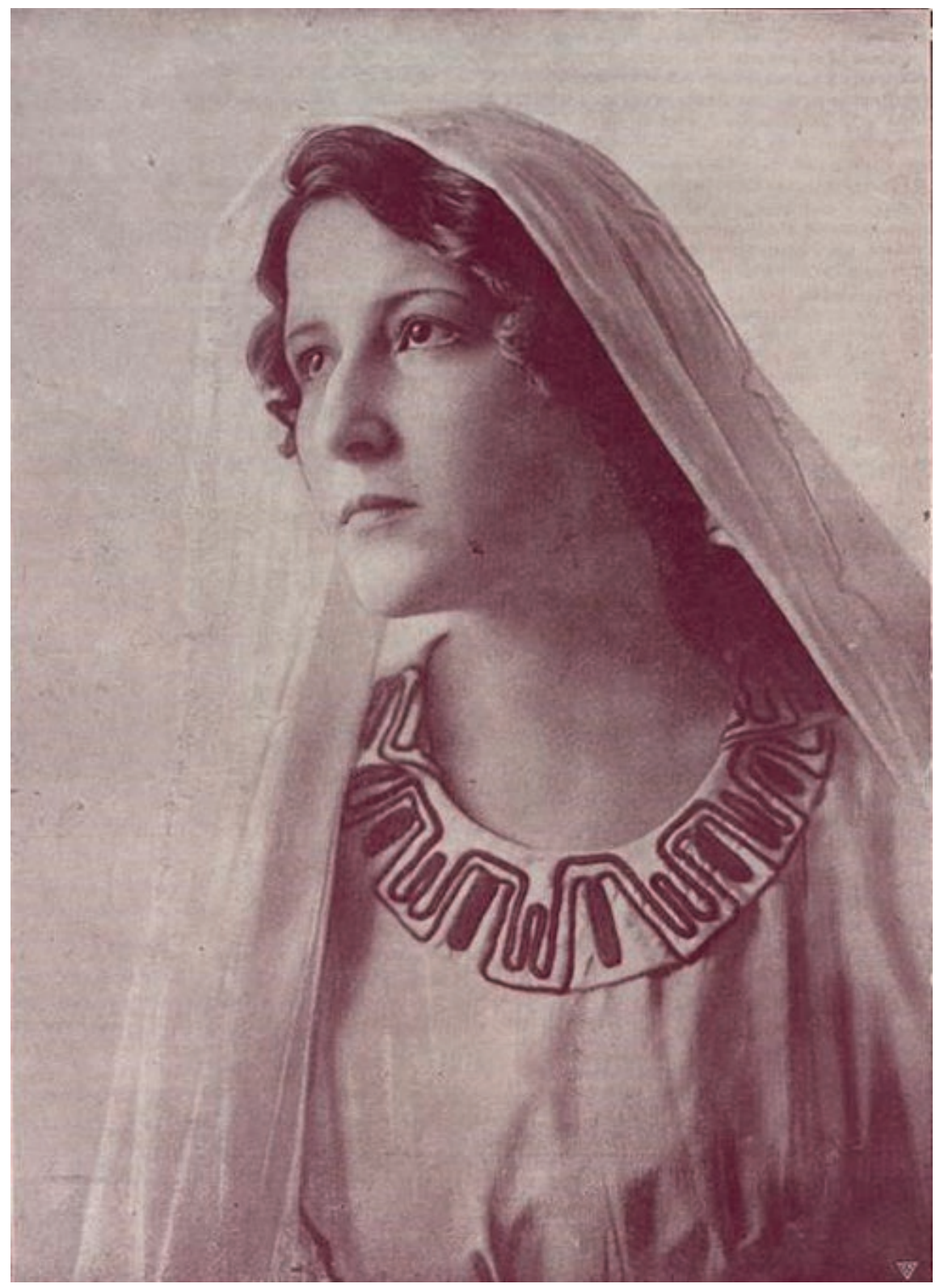

Fig. 18. "Paquita Baylina, de Porto Alegre", foto publicada na edição de setembro/outubro da revista Bahia Illustrada. Fonte: (BAHIA ILLUSTRADA, 1919).

Note-se, na citação, como o pretendente de Paquita insinua que a sua eventual beleza está condicionada à paixão e graça advindas da experiência amorosa ("não há 
beleza sem amor"). Além disso, a reprodução da imagem indica uma mulher quase santificada: olhar para cima, expressão serena e delicada, véu recobrindo cabelos e ombros como uma virgem-maria: "Ninguém, no entanto, te conhece, na essência luminosa de tua virgindade, na ebriez angelica de teu impressentido carinho... Já agora me poderia encontrar em ti mesma [...]. Se não mais te vejo, ficarei amando a tua illusão ou a tua sombra (BAHIA ILLUSTRADA, 1919)".

Eis um olhar sobre a mulher, idealizada e pura, ainda que projetada sob a sombra de uma ilusão. Não é de se espantar, portanto, que certas expressões incorporadas ao vocabulário do inconsciente coletivo tenham alcançado nossos dias: "está pronta para casar"; "esta moça é prendada"; "vai ficar para titia"; "moça de família"; sem mencionar as propaladas "escolas de princesa" recentemente inauguradas no Brasil que, em sua concepção, remontam grande parte dos paradigmas educacionais impostos às mulheres desde princípios do século XIX. Lugar de mulher casada é no palco, fazendo música? Para Paquita, cem anos atrás, não foi.

Talentosa e dedicada, o seu caso é representativo de como um olhar mais atento sobre a atuação musical das mulheres pode oferecer um entendimento mais amplo sobre as práticas musicais de um determinado período. Além disso, seu percurso artístico reflete um preciso retrato desta curva de momentos pontuais projetados, à época, sobre a vida de uma mulher: a musicista começa a se apresentar na cena artística porto-alegrense em 1910; nos anos seguintes, ganha paulatino prestígio e se torna figura reconhecida na cidade após, em 1914, vencer um concurso instrumental; a partir de então, realiza dezenas de apresentações nos principais teatros, salões, igrejas e espaços da cidade, sendo saudada pela imprensa como uma virtuose em três instrumentos e assumindo a condição de cantora amplamente requisitada, inclusive com registros de excelente desempenho acadêmico. Por mais de uma década, protagoniza uma agenda musical intensa e diversificada.

E aí, o corte brusco: em 23 de junho de 1923, casa-se com Cezar Augusto de Souza e seu nome simplesmente desaparece da imprensa gaúcha. Notícias sobre ela só voltarão a despontar nos jornais quando do seu falecimento, ocorrido quase quatro décadas depois, no Rio de Janeiro (30 abri. 1962) ${ }^{7}$.

Dentro da concepção positivista vigente no Rio Grande do Sul no final de século XIX e começos do século XX, a educação musical feminina deveria ser necessariamente tendo em vista que a mulher era a responsável pela educação dos filhos, e deveria ser capaz de bem realizá-la (PORTO; NOGUEIRA, 2007, p. 4)

\footnotetext{
7 É possivel que a mudança para o Rio de Janeiro também tenha influenciado o seu distanciamento dos palcos, mas parece-nos mais provável que o casamento tenha sido, de fato, o principal motivo, já que Paquita permaneceu ausente das atividades artísticas durante 2/3 de sua vida (tempo suficiente para ter reorganizado a carreira e estabelecido uma rede mínima de contatos, se fosse o caso). Aliás, muito pouco se sabe sobre a permanência da artista no Rio de Janeiro, já que - se ocorreram - os jornais não registraram quaisquer de suas apresentações durante tais décadas. Se aprofundadas, questões em aberto sobre a estada em terras cariocas podem elucidar pontos ainda obscuros em sua biografia: 1) tendo como fagulha os anúncios fúnebres, talvez seja possivel localizar o túmulo de Paquita, a fim de tentar averiguar seu ano de nascimento; 2) As menções à sua irmã e mãe nos jornais cariocas (processos judiciais, etc.) fazem referência a um Documento Nacional de Identidade (D.N.I.), documento de identificação similar ao Registro de Identidade brasileiro (RG) e comum em países de língua hispânica (como Espanha, Argentina, etc.), o que nos sugere que Paquita pertencia a uma família de imigrantes. Tal apontamento se desdobra ainda em questões secundárias: de que país teriam vindo? Em que ano chegaram ao Brasil? Paquita era brasileira nata? Quem foi o pai de Paquita? Por que escolheram o Rio Grande do Sul como destino?
} 
O casamento parece ter representado para Paquita, portanto, um fim assertivo para as suas apresentações públicas. E não somente em relação à música, mas também no que diz respeito a todas as atividades desempenhadas por ela antes do matrimônio.

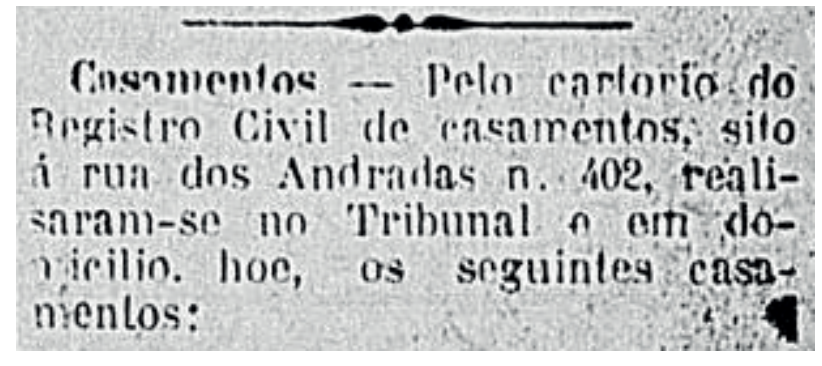

$[\ldots]$

\section{Gezar Augusto de Souza e d. Pa-} quila Angelima Bnylina; si. Arlin-

Fig. 19. Registro do casamento de Paquita Baylina e Cezar Augusto de Souza publicado na imprensa gaúcha em 23 de junho de 1923. Após essa data, não foram encontradas notícias de apresentações musicais protagonizadas pela artista. Fonte: (A FEDE-

$$
\text { RAÇÃO, 1923a). }
$$

Sua irmã, Maria Baylina, viveu processo parecido, o que nos ajuda a compreender, pelo menos em parte, porque ainda hoje, sobretudo no violão, há uma enorme discrepância na quantidade de praticantes do instrumento entre os sexos masculino e feminino, com preponderância absoluta dos primeiros. E porque - ao pensar nos principais nomes do violão brasileiro - a franca maioria (para não dizer a totalidade) dos personagens rememorados - de ontem ou de agora - são homens. Certamente não foi por falta de capacidade ou dedicação, conforme indica o caso de Paquita Baylina.

\section{Considerações finais}

Com as quase 100 fontes suscitadas em revistas e jornais (sobretudo gaúchos) das primeiras décadas do século XX, é possível indicar que Paquita Baylina teve uma significativa atuação como musicista no Rio Grande do Sul entre os anos de 1910 e 1923.

Apesar de não haver registros de apresentações públicas suas empunhando o bandolim, algo que talvez tenha sido instigado pelo fato da irmã tê-lo como instrumento principal, é bem provável que a musicista também o dominasse, conforme sugere a nota assinada pelo crítico musical do jornal O Exemplo, classificando-a de "distincta virtuose de guitarra, bandolim e piano" (O EXEMPLO, 1919b). Aliás, esta não foi a única celebração de suas habilidades instrumentais na imprensa gaúcha. Em outro momento, a "conterrânea" foi batizada com o título de "exímia pianista" e "inteligente guitarrista" (A FEDERAÇÃO, 1917f). Finalmente, não foram poucas as vezes em que suas performances arrancaram aplausos calorosos do público e resenhas entusiásticas dos jornais locais. Somados, estes fatores são indícios concretos do quão o seu nível musical parece ter sido, de fato, o de uma artista com algum destaque dentre os artistas amadores que figuravam nos clubes musicais de Porto Alegre. 
Especificamente em relação ao violão, Paquita Baylina atuou de forma tripla no Rio Grande do Sul:

1) Foi a primeira mulher de que temos notícia a apresentar peças do repertório clássico do instrumento nos principais teatros da cidade, muitos dos quais vinculados majoritariamente a uma tradição da música de concerto. Além disso, empunhando o violão, Paquita chegou a vencer um concurso instrumental promovido pelo Instituto Musical, em 1914, do qual participaram outras duas concorrentes tocando bandolim;

2) Também foi, na região, desbravadora na prática simultânea do canto com acompanhamento de violão;

3) Embora não haja uma fonte explícita que ateste a proposição, podemos sugerir que Paquita foi ainda uma das primeiras mulheres de que se tem notícia a ensinar violão em Porto Alegre, uma vez que foi este o seu instrumento principal e diversos jornais a mencionam, genericamente, como "professora" nas divulgações de suas apresentações. É provável que ela o ensinasse não exclusivamente, mas paralelamente aos outros instrumentos musicais que dominava (piano, bandolim e canto).

Como apêndice, depois das referências, apresentamos uma tabela que reúne as informações básicas de 20 apresentações realizadas por Paquita, em Porto Alegre, em pouco mais de uma década de atuação (1910-1921). Sete delas ocorreram no Theatro São Pedro e metade foi realizada com o violão em punhos, seja como solista, acompanhante ou camerista. Aliás, este último número deve ser ainda maior, uma vez que registramos outros sete exemplos sem indicação do instrumento que foi utilizado em suas performances.

Finalmente, a atuação múltipla da musicista demonstra que, na cena musical de Porto Alegre, o violão se inseria em contextos socioculturais diversos já em princípios do século $X X$, incluindo a sua presença desde blocos carnavalescos que atuavam nas ruas até salões e teatros mais vinculados à tradição da "música de concerto". Na região, não houve um percurso linear e evolutivo de inserção do instrumento entre personagens, classes e espaços sociais, mas conexões que foram se estabelecendo a partir de uma rede de construção rizomática (DELEUZE; GUATTARI, 2000), ou seja, de maneira heterogênea, sem um centro definido e com múltiplas portas de entrada e saída. Nas décadas iniciais dos anos novecentos, esta "transitividade" (LLANOS, 2018) marcante na trajetória do violão no Brasil também se manifesta de forma percuciente nas dinâmicas culturais da sociedade gaúcha. O seguinte apontamento de Porto e Nogueira ratifica tal perspectiva:

Torna-se interessante a observação detida da presença feminina nas estudantinas executando o violão, entre mandolas e bandurrias, porque a bibliografia específica sobre música brasileira considera que o violão no Brasil, neste momento, era um instrumento associado às classes menos abastadas e à nascente música popular brasileira (2007, p. 3). 
A par de sua significativa inserção no cenário cultural de Porto Alegre (de forma global) e da visibilidade que conferiu ao violão em determinados espaços sociais (de forma particular), Paquita Baylina teve sua trajetória artística duplamente silenciada: ainda em vida, através de um casamento que parece ter encerrado definitivamente suas aparições públicas como musicista; depois de sua morte, pelo fato de que muito pouco se pesquisou e se sabe, ainda, sobre a contribuição das mulheres para as trajetórias do violão no Brasil, especialmente nas regiões não contempladas no eixo RJ-SP. Este artigo visa resgatar parte de sua memória, retirando seu nome do silêncio histórico e oferecendo algumas das fagulhas necessárias para o aprofundamento em futuras pesquisas.

\section{Referências}

AMARAL, Mayara. A mulher compositora e o violão da década de 1970: vertentes analíticas e contextualização histórico-estilística. Dissertação (Mestrado em Música). Escola de Música e Artes Cênicas, Universidade Federal de Goiás, Goiânia, 2017.

AMORIM, Humberto. O ensino de música nas primeiras décadas do Brasil oitocentista (1808-1822). Opus - Revista Eletrônica da ANPPOM. Campinas, v. 23, n. 3, p. 43-66, 2017.

CORTE REAL, Antônio. Subsídios para a História da Música no Rio Grande do Sul. 2ed. Porto Alegre: Movimento, 1984.

DELEUZE, Gilles; GUATTARI, Félix. Mil Platôs: capitalismo e esquizofrenia. São Paulo, Ed. 34, 2000.

LACERDA, Luisa Damaceno de. Memórias compostas: narrativas de cantorascompositoras no Rio de Janeiro. Dissertação (Mestrado em Música). Instituto VillaLobos, Universidade Federal do Estado do Rio de Janeiro, Rio de Janeiro, 2017.

LLANOS, Carlos Fernando Elías. Nem erudito, nem popular: por uma identidade transitiva do violão brasileiro. Tese (Doutorado em Música). Escola de Comunicação e Artes, Universidade de São Paulo, São Paulo, 2018.

PORTO, Patrícia Pereira; NOGUEIRA, Isabel Porto. Imagem e representação em mulheres violonistas: algumas reflexões sobre Josefina Robledo. In: CONGRESSO DA ASSOCIAÇÃO NACIONAL DE PESQUISA E PÓS-GRADUAÇÃO EM MÚSICA (ANPPOM), XVII, São Paulo, Anais... 2007, p.1-12.

RUAS JUNIOR, J. J. P. O violão feminino na Primeira República: Um viés através da Revista O Violão. In: IV SIMPÓSIO INTERNACIONAL DE MUSICOLOGIA, IV, 2014, Pirenópolis. Anais..., 2014. v. 1. p.275-280. 
TABORDA, M. E. As senhoritas e o violão: os anos 20 na capital irradiante. In: CONGRESSO DA ASSOCIAÇÃO NACIONAL DE PESQUISA E PÓS-GRADUAÇÃO EM MÚSICA (ANPPOM), XVII, João Pessoa (PB), Anais... 2012, p.1-12.

\section{Periódicos}

A FEDERAÇÃO, Porto Alegre, 26 nov. 1910, p.4. Porto Alegre, 20 jul. 1912, p.1.

Porto Alegre, 22 mar. 1914a, p.10. Porto Alegre, 24 mar. 1914b, p.6. Porto Alegre, 8 abr. 1914c, p.6. Porto Alegre, 18 set. $1914 d$, p.7. Porto Alegre, 19 set. 1914e, p.3. Porto Alegre, 13 dez. 1914f, p.5. Porto Alegre, 16 dez. 1914g, p.4. Porto Alegre, 4 abr. 1914h, p.5. Porto Alegre, 14 mai. 1914i, p.6. Porto Alegre, 28 dez. 1915a, p.3. Porto Alegre, 19 fev. 1915b, p.3. Porto Alegre, 2 out. 1915c, p.7. Porto Alegre, 12 jan. 1915d, p.4. Porto Alegre, 26 out. 1915e, p.4. Porto Alegre, 6 out. 1916a, p.4. Porto Alegre,13 nov. 1916b, p.5. Porto Alegre, 18 abr. 1917a, p.3. Porto Alegre, 27 out. 1917b, p.6. Porto Alegre, 7 dez. 1917c, p.3. Porto Alegre, 27 set. 1917d, p.3. Porto Alegre, 29 set. 1917e, p.3. Porto Alegre, 03 fev. 1917f, p.3. Porto Alegre, 06 fev. 1917g, p.7. Porto Alegre, 07 fev. 1917h, p.5. Porto Alegre, 08 fev. 1917i, p.5. Porto Alegre, 09 fev. 1917j, p.2. Porto Alegre, 3 out. 1917l, p.6. Porto Alegre, 24 dez. 1917m, p.3. Porto Alegre, 17 nov. 1917n, p.5. Porto Alegre, 27 jun. 1918a, p.3. Porto Alegre, 31 jul. 1918b, p.6. Porto Alegre, 2 ago. 1918c, p.4. Porto Alegre, 6 ago. 1918d, p.6. Porto Alegre, 27 ago. 1918e, p.6. Porto Alegre, 13 set. $1918 f$, p.7. 
Porto Alegre, 23 fev. 1918g, p.5.

Porto Alegre, 23 set. 1918h, p.3.

Porto Alegre, 27 out. 1919a, p.5.

Porto Alegre, 24 jan. 1919b, p.5.

Porto Alegre, 12 fev. 1919c, p.4.

Porto Alegre, 19 ago. 1919d, p.7.

Porto Alegre, 8 mai. 1920a, p.5.

Porto Alegre, 4 ma. 1920b, p.6.

Porto Alegre, 3 abr. 1920c, p.6.

Porto Alegre, 13 abr. 1920d, p.4.

Porto Alegre, 13 fev. 1920e, p.4.

Porto Alegre, 14 fev. 1920f, p.2.

Porto Alegre, 16 fev. 1920g, p.1.

Porto Alegre, 16 abr. 1920h, p.4.

Porto Alegre, 14 mai. 1920i, p.4.

Porto Alegre, 23 jul. 1920j, p.2.

Porto Alegre, 31 mar. 1921a, p.4.

Porto Alegre, 15 set. 1921b, p.5.

Porto Alegre, 19 jan. 1921c, p.6.

Porto Alegre, 26 nov. 1921d, p.5.

Porto Alegre, 12 set. 1921e, p.5.

Porto Alegre, 14 set. 1921f, p.5.

Porto Alegre, 15 set. 1921g, p.4.

Porto Alegre, 16 set. 1921h, p.4.

Porto Alegre, 2 dez. 1921i, p.2.

Porto Alegre, 3 dez. 1921j, p.2.

Porto Alegre, 31 ago. 1921L, p.5.

Porto Alegre, 4 abr. 1922a, p.3.

Porto Alegre, 5 mai. $1922 b$, p.7.

Porto Alegre, 19 mai. 1922c, p.5.

Porto Alegre, 3 jun. 1922d, p.2.

Porto Alegre, 1이․ 1922e, p.2.

Porto Alegre, 23 jun. 1923a, p.5.

Porto Alegre, 14 mai. 1923b, p.4.

A NOITE, Rio de Janeiro, 20 jun. 1936, p.34.

Rio de Janeiro, 22 mai. 1950, p.6.

BAHIA ILLUSTRADA, Ano III, n.22-23, set/ out. 1919, p.36.

CORREIO DA MANHÃ, Rio de Janeiro, 6 mai. 1962, p.9 (2 caderno).

DIARIO DE NOTICIAS, Rio de Janeiro, 19 out. 1956, p.4 (2ª seção). 
GAZETA DE NOTICIAS, Rio de Janeiro, 25 mar. 1914, p.6.

JORNAL DO BRASIL, Rio de Janeiro, 23 jun. 1989, p.8.

O EXEMPLO, Porto Alegre, 25 jul. 1919a, p.5.

Porto Alegre, 9 fev. 1919b, p. 2.

VIDA SPORTIVA, Rio de Janeiro, 4 jan. 1919, p.2-3.

\section{Apêndice - Tabela 01}

\begin{tabular}{|c|c|c|c|c|}
\hline Data & Local & Instrumento & Repertório & Fonte \\
\hline 28 nov. 1910 & $\begin{array}{c}\text { Theatro } \\
\text { São Pedro }\end{array}$ & violão solo & $\begin{array}{c}\text { mazurca La } \\
\text { Perezosa, } \\
\text { de Juan Alais }\end{array}$ & $\begin{array}{l}\text { A Federação } \\
\text { (1910) }\end{array}$ \\
\hline 20 jul. 1912 & Club Caixeiral & $\begin{array}{l}\text { violão em duo } \\
\text { com bandolim }\end{array}$ & $\begin{array}{c}\text { gavota } \\
\text { Stephanie }\end{array}$ & $\begin{array}{l}\text { A Federação } \\
\text { (1912) }\end{array}$ \\
\hline 22 mar. 1914 & Club Caixeiral & $\begin{array}{l}\text { violão solo } \\
\text { (participação } \\
\text { em concurso) }\end{array}$ & $\begin{array}{c}\text { Grand Sonata, } \\
\text { de Fernando } \\
\text { Sor }\end{array}$ & $\begin{array}{l}\text { A Federação } \\
\text { (1914a; 1914b) }\end{array}$ \\
\hline 08 abr. 1914 & $\begin{array}{c}\text { Theatro } \\
\text { São Pedro }\end{array}$ & $\begin{array}{l}\text { trio: violão, } \\
\text { bandolim } \\
\text { e mandola }\end{array}$ & $\begin{array}{c}\text { Garota, } \\
\text { de José Faini }\end{array}$ & $\begin{array}{l}\text { A Federação } \\
\text { (1914c) }\end{array}$ \\
\hline 18 set. 1914 & $\begin{array}{c}\text { Teatro do } \\
\text { Centro } \\
\text { Católico do RS }\end{array}$ & $\begin{array}{l}\text { trio: violão, } \\
\text { bandolim } \\
\text { e mandola }\end{array}$ & $\begin{array}{c}\text { Serenata - } \\
\text { Fantasia, } \\
\text { de O. Munier }\end{array}$ & $\begin{array}{l}\text { A Federação } \\
\text { (1914d) }\end{array}$ \\
\hline 18 set. 1914 & $\begin{array}{c}\text { Teatro do } \\
\text { Centro } \\
\text { Católico do RS. }\end{array}$ & violão solo & $\begin{array}{c}\text { Fantasia } \\
\text { Original, } \\
\text { de J. Viñas. }\end{array}$ & $\begin{array}{l}\text { A Federação } \\
\text { (1914d) }\end{array}$ \\
\hline 19 dez. 1914 & $\begin{array}{l}\text { Theatro } \\
\text { São Pedro }\end{array}$ & [sem descrição] & [sem descrição] & $\begin{array}{c}\text { A Federação } \\
(1914 \mathrm{e})\end{array}$ \\
\hline 02 out. 1915 & $\begin{array}{l}\text { Comitato } \\
\text { Italiano Pró- } \\
\text { Pátria }\end{array}$ & [sem descrição] & [sem descrição] & $\begin{array}{l}\text { A Federação } \\
\text { (1915c) }\end{array}$ \\
\hline 17 jan. 1917 & Club Caixeiral & $\begin{array}{l}\text { piano, em duo } \\
\text { com bandolim }\end{array}$ & $\begin{array}{l}\text { Mazurca, } \\
\text { Fantasia }\end{array}$ & $\begin{array}{l}\text { A Federação } \\
(1915 d)\end{array}$ \\
\hline 03 fev. 1917 & $\begin{array}{c}\text { Salão do } \\
\text { Palacete Rocco } \\
\text { (confeitaria) }\end{array}$ & piano & $\begin{array}{l}\text { Mazurca n. 2, } \\
\text { de Kodá }\end{array}$ & $\begin{array}{l}\text { A Federação } \\
(1917 f)\end{array}$ \\
\hline
\end{tabular}




\begin{tabular}{|c|c|c|c|c|}
\hline Data & Local & Instrumento & Repertório & Fonte \\
\hline 27 set. 1917 & $\begin{array}{c}\text { Theatro Infantil } \\
\text { (estreia) }\end{array}$ & [sem descrição] & [sem descrição] & $\begin{array}{c}\text { A Federação } \\
(1917 d)\end{array}$ \\
\hline 29 set. 1917 & $\begin{array}{c}\text { Teatro do } \\
\text { Centro } \\
\text { Católico do RS }\end{array}$ & [sem descrição] & [sem descrição] & $\begin{array}{c}\text { A Federação } \\
(1917 e)\end{array}$ \\
\hline 19 nov. 1917 & $\begin{array}{c}\text { Theatro } \\
\text { São Pedro }\end{array}$ & $\begin{array}{l}\text { Coro feminino } \\
\text { a } 3 \text { vozes }\end{array}$ & $\begin{array}{c}\text { Pardon Breton, } \\
\text { de Cécile } \\
\text { Chaminade }\end{array}$ & $\begin{array}{c}\text { A Federação } \\
(1917 n)\end{array}$ \\
\hline 06 ago. 1918 & Club Caixeiral & [sem descrição] & [sem descrição] & $\begin{array}{c}\text { A Federação } \\
\text { (1918d) }\end{array}$ \\
\hline 26 ago. 1918 & $\begin{array}{l}\text { Theatro } \\
\text { São Pedro }\end{array}$ & canto e violão & $\begin{array}{l}\text { Cigarro do } \\
\text { Soldado }\end{array}$ & $\begin{array}{c}\text { A Federação } \\
(1918 \mathrm{e})\end{array}$ \\
\hline 12 set. 1918 & $\begin{array}{c}\text { Club do } \\
\text { Commercio }\end{array}$ & canto & Canção & $\begin{array}{c}\text { A Federação } \\
\text { (1918f) }\end{array}$ \\
\hline 12 fev. 1919 & $\begin{array}{c}\text { Cineteatro } \\
\text { Thalia }\end{array}$ & $\begin{array}{l}\text { "canto à } \\
\text { guitarra" }\end{array}$ & [sem descrição] & $\begin{array}{c}\text { A Federação } \\
(1919 c)\end{array}$ \\
\hline 14 fev. 1920 & $\begin{array}{c}\text { Theatro } \\
\text { São Pedro }\end{array}$ & $\begin{array}{l}\text { "canto à } \\
\text { guitarra" }\end{array}$ & [sem descrição] & $\begin{array}{c}\text { A Federação } \\
(1920 \text { e) }\end{array}$ \\
\hline 03 abr. 1920 & $\begin{array}{c}\text { Centro } \\
\text { Musical Porto- } \\
\text { alegrense }\end{array}$ & [sem descrição] & [sem descrição] & $\begin{array}{c}\text { A Federação } \\
\text { (1920c) }\end{array}$ \\
\hline 05 mai. 1920 & $\begin{array}{l}\text { Theatro } \\
\text { São Pedro }\end{array}$ & [sem descrição] & [sem descrição] & $\begin{array}{c}\text { A Federação } \\
\text { (1920h) }\end{array}$ \\
\hline 14 mai. 1920 & Club Caixeiral & $\begin{array}{c}\text { "canções ao } \\
\text { violão" }\end{array}$ & [sem descrição] & $\begin{array}{c}\text { A Federação } \\
(1920 i)\end{array}$ \\
\hline 16 set. 1921 & $\begin{array}{l}\text { Igreja N. S. } \\
\text { das Dores }\end{array}$ & canto & Ave-Maria ${ }^{8}$ & $\begin{array}{c}\text { A Federação } \\
(1921 \mathrm{~h})\end{array}$ \\
\hline
\end{tabular}

Tab. 1. Apresentações de Paquita Baylina realizadas em Porto Alegre entre os anos de 1910 e 1921.

Fonte: elaboração dos autores.

8 Infelizmente, não há informações sobre o compositor, versão e/ou instrumentação utilizada por Paquita Baylina para cantar a Ave-Maria, mas é muito provável que ela própria fizesse o acompanhamento ao violão, já que não há, em todos os exemplos coletados, quaisquer registros nominais de músicos ou musicistas que tenham eventualmente desempenhado a função. Também é preciso registrar que, embora Paquita tenha performado a Ave-Maria em diversas ocasiões e igrejas (coletamos oito incidências, mas o número é certamente maior), optamos por indicar, na tabela, apenas o primeiro caso, uma vez que se trata do mesmo repertório repetido em contextos próximos. 